Article

\title{
New synthetic inhibitors of fatty acid synthase with anticancer activity
}

Carlos Turrado, Teresa Puig, Javier García Cárceles, Marta Artola, Bellinda

Benhamu, Silvia Ortega-Gutierrez, Joana Relat, Gloria Oliveras, Adriana Blancafort,

Diego Haro, Pedro F. Marrero, Ramón Colomer, and Maria Luz Lopez-Rodríguez

J. Med. Chem., Just Accepted Manuscript • DOI: 10.1021/jm2016045 • Publication Date (Web): 04 May 2012

Downloaded from http://pubs.acs.org on May 14, 2012

\section{Just Accepted}

"Just Accepted" manuscripts have been peer-reviewed and accepted for publication. They are posted online prior to technical editing, formatting for publication and author proofing. The American Chemical Society provides "Just Accepted" as a free service to the research community to expedite the dissemination of scientific material as soon as possible after acceptance. "Just Accepted" manuscripts appear in full in PDF format accompanied by an HTML abstract. "Just Accepted" manuscripts have been fully peer reviewed, but should not be considered the official version of record. They are accessible to all readers and citable by the Digital Object Identifier (DOI®). "Just Accepted" is an optional service offered to authors. Therefore, the "Just Accepted" Web site may not include all articles that will be published in the journal. After a manuscript is technically edited and formatted, it will be removed from the "Just Accepted" Web site and published as an ASAP article. Note that technical editing may introduce minor changes to the manuscript text and/or graphics which could affect content, and all legal disclaimers and ethical guidelines that apply to the journal pertain. ACS cannot be held responsible for errors or consequences arising from the use of information contained in these "Just Accepted" manuscripts. 


\title{
New synthetic inhibitors of fatty acid synthase with
}

\section{anticancer activity}

\author{
Carlos Turrado, ${ }^{1}$ Teresa Puig, ${ }^{2}$ Javier García-Cárceles, ${ }^{1}$ Marta Artola, ${ }^{1}$ Bellinda Benhamú, ${ }^{1}$ Silvia \\ Ortega-Gutiérrez, ${ }^{1}$ Joana Relat, ${ }^{3}$ Gloria Oliveras, ${ }^{2}$ Adriana Blancafort, ${ }^{2}$ Diego Haro, ${ }^{3}$ Pedro F. Marrero, ${ }^{3}$ \\ Ramón Colomer, ${ }^{4}$ and María L. López-Rodríguez ${ }^{1, *}$
}

${ }^{1}$ Departamento de Química Orgánica I, Facultad de Ciencias Químicas, Universidad Complutense de Madrid, E-28040 Madrid, Spain; ${ }^{2}$ Oncology, Girona Institute for Biomedical Research, E-17001 Girona, Spain and School of Medicine, University of Girona, E-17071 Girona, Spain; ${ }^{3}$ Biochemistry and Molecular Biology, School of Pharmacy and Institute of Biomedicine of the University of Barcelona (IBUB), 08028 Barcelona, Spain; ${ }^{4}$ Spanish National Cancer Research Center (CNIO), Clinical Research Program, Melchor Fernández Almagro, 3, E-28029, Madrid, Spain

*To whom correspondence should be addressed.

Phone, (+34) 913944239; fax, (+34) 913944103; e-mail, mluzlr@quim.ucm.es.

RECEIVED DATE

TITLE RUNNING HEAD: New synthetic FASN inhibitors 
${ }^{a}$ Abbreviations: CPT-1, carnitine palmitoyltransferase-1; DIC, diisopropylcarbodiimide; DIEA, diisopropylethylamine; EDC, 1-ethyl-3-(3-dimethylaminopropyl)carbodiimide; EGCG, (-)epigallocatechin-3-gallate; FASN, fatty acid synthase; FBS, fetal bovine serum; HOBt, 1hydroxybenzotriazole; i.p., intraperitoneal; MTT, 3-(4,5-dimethyl-1,3-thiazol-2-yl)-2,5-diphenyl-2Htetrazol-3-ium bromide; PARP, poly(ADP-ribose) polymerase; PBS, phosphate buffered solution; PS, polymer supported; SDS, sodium dodecylsulphate; SEM, standard error of the mean; TBS-T, Trisbuffered solution with $0.05 \%$ Tween 20 ; TEA, triethylamine. 


\begin{abstract}
Fatty acid synthase (FASN) is a lipogenic enzyme that is highly expressed in different human cancers. Here we report the development of a new series of polyphenolic compounds 5-30 that have been evaluated for their cytotoxic capacity in SK-Br3 cells, a human breast cancer cell line with high FASN expression. The compounds with an $\mathrm{IC}_{50}<50 \mu \mathrm{M}$ have been tested for their ability to inhibit FASN activity. Among them, derivative $\mathbf{3 0}$ blocks the $90 \%$ of FASN activity at low concentration $(4 \mu \mathrm{M})$, is highly cytotoxic in a broad panel of tumor cells, induces apoptosis, and blocks the activation of HER2, AKT and ERK pathways. Remarkably, 30 does not activate carnitine palmitoyltransferase-1 (CPT-1) nor induces in mice weight loss, which are the main drawbacks of other previously described FASN inhibitors. Thus, FASN inhibitor $\mathbf{3 0}$ may aid the validation of this enzyme as a therapeutic target for the treatment of cancer.
\end{abstract}

KEYWORDS. FASN, fatty acid synthase inhibitors, CPT-1, carnitine palmitoyltransferase-1, structureaffinity relationship, polyphenols, anticancer activity, breast cancer 


\section{Introduction}

Altered lipogenesis is a hallmark of many types of cancer and there is evidence that links overexpression and overactivation of the lipogenic enzymes that are involved in de novo lipid biosynthesis with different human tumors. ${ }^{1}$ A key step in elucidating the relationship between cancer and lipogenesis was the identification of the oncogenic antigen-519 (OA-519), a protein linked to poor prognosis in breast cancer patients, as fatty acid synthase $\left(\mathrm{FASN}^{a}\right){ }^{2}$ Since that initial finding, increased FASN expression level has been observed in a wide variety of solid human tumors, including cancers of breast, prostate, colon, lung, bladder, ovary, stomach, endometrium, kidney, skin, esophagus, tongue, and soft tissues. In addition, FASN overexpression occurs early in tumor progression and is associated with the unfavorable outcomes of the most aggressive tumors. ${ }^{3}$ Thus, FASN has been considered as a metabolic oncogene. ${ }^{4}$ In addition, FASN inhibition induces apoptosis selectively in human cancer cells both in vitro and in vivo, with minimal effect on normal cells. ${ }^{3}$ This fact, directly related to the high dependence of the cancer cells on de novo fatty acid synthesis and to the differential expression of FASN, makes this enzyme a suitable target for cancer treatment with a potential good therapeutic index. Indeed, pharmacological inhibitors of FASN that block tumor cell proliferation, elicit tumor cell death, and prevent tumor growth in animal models have been identified. ${ }^{1,3}$ These studies confirmed the proposed use of FASN inhibitors as novel antitumor therapeutics. The most representative FASN inhibitors are shown in Chart 1 . Cerulenin [(2R,3S)-3-[(4E,7E)-nona-4,7-dienoyl]oxirane-2carboxamide, 1], a metabolite produced by the fungus Cephalosporum caerulens, was the first characterized FASN inhibitor. ${ }^{5}$ It induced selective cytotoxicity in various types of cancer cells and showed promising effects in different cancer xenograft models. However, the presence of the reactive epoxide ring makes cerulenin susceptible to other nonspecific ring-opening reactions, feature that has limited any potential clinical application. ${ }^{1,3,6}$ To overcome this drawback, related analog C75 (trans-4carboxy-5-octyl-3-methylenebutyrolactone, 2, Chart 1) was synthesized. ${ }^{7}$ As expected from its capacity to inhibit FASN activity, 2 showed significant antitumor effects on several cancer cell lines and 
xenograft models. ${ }^{3}$ However, it has been suggested that 2 could be sensitive to the presence of endogenous thiols. ${ }^{8}$ In addition, both $\mathbf{1}$ and $\mathbf{2}$ induce a profound weight loss, which is far from ideal for cancer patients undergoing chemotherapy. This side effect is apparently due to their activity in increasing fatty acid oxidation through direct activation of carnitine palmitoyltransferase-1 (CPT-1). ${ }^{9-11}$ Also, they reduce food intake by blocking the production of hypothalamic neuropeptide-Y. ${ }^{11}$ These effects clearly hindered the further clinical development of $\mathbf{1}$ and 2. In 2004, orlistat [(-)tetrahydrolipstatin, 3, Chart 1], marketed as anti-obesity drug, was found to inhibit FASN, ${ }^{12}$ and more recently, green tea polyphenols, especially highly abundant catechins such as (-)-epigallocatechin 3gallate (EGCG, 4, Chart 1), have received much attention on the grounds of their reported capacity to block the formation and development of tumors in a variety of animal models. ${ }^{13}$ Furthermore, EGCG has been found to inhibit FASN and to induce selective apoptosis in human breast and prostate cancer cells ${ }^{14-16}$ without producing concomitant weight loss. ${ }^{17}$ Unfortunately, its effectiveness in vivo is quite limited due to its high $\mathrm{IC}_{50}$ value, poor oral bioavailability, and low serum stability. ${ }^{18}$ In our research group, we are involved in a project aimed at the development of new FASN inhibitors devoid of CPT-1 stimulation as side effect with the objective of advancing towards the validation of FASN as a new therapeutic target for the treatment of cancer. Based on our promising preliminary results with some structurally simple molecules initially inspired on the polyphenolic nature of EGCG that showed significant in vitro and in vivo antitumor properties, ${ }^{19,20}$ in the present work we report a new series of gallate derivatives in which the A subunit has been modified (compounds 5-30, Chart 1). Among them, derivative $\mathbf{3 0}$ stands out as a highly cytotoxic compound in a broad panel of tumor cells of different tissue origins $\left(\mathrm{IC}_{50}\right.$ values ranging from 1.4 to $\left.9 \mu \mathrm{M}\right)$. Furthermore, compound $\mathbf{3 0}$ almost completely abrogates FASN activity at a concentration of $4 \mu \mathrm{M}$ in breast cancer SK-Br3 cells, induces apoptosis of tumor cells, and interferes with the mitogen-activated protein kinase (MAPK) pathway. Importantly, all these sought-after effects occur without parallel CPT-1 stimulation or weight loss induction. Overall, the possibility of inhibiting FASN without concomitant weight loss induction clearly highlights the potential of this enzyme as a new target in oncology. Accordingly, FASN inhibitors could become a new class of 
drugs that aid in the challenging endeavor of handling those types of tumors resistant to the current therapies or those lacking adequate treatments.

\section{Results and Discussion}

Synthesis of compounds 5-30. In a previous study, and initially inspired by the polyphenolic nature of EGCG, we designed a small series of compounds structurally simpler than this natural product and with a straightforward synthetic accessibility. Encouraged by the interesting results, ${ }^{20}$ in the present work we have expanded the structural variability and we have studied the influence of the A subunit in the cytotoxicity and FASN inhibition of compounds 5-30 (Chart 1). Anticipating the need of a synthetic route that enabled us both the quick generation of a variety of compounds as well as their synthesis on the gram-scale needed for in vivo studies, we set up a methodology for the esterification reaction based on the use of polymer supported (PS) reagents (Scheme 1, Method A). For this purpose, different commercially available PS reagents were tested, including Mukaiyama (PS-Mukaiyama), dicyclohexyland 1-ethyl-3-(3-dimethylaminopropyl)carbodiimide (PS-DCC and PS-EDC, respectively), and a $N, N^{\prime}$ dimethylaminopyridine surrogate bound to polystyrene (PS-DMAP). However, all these reagents led to different and non-desired outcomes, such as the isolation of mixtures of esterification product and the corresponding acid anhydride (with PS-Mukaiyama), of the activated alcohol intermediate (PS-DMAP), or a lack of reactivity of the protected gallic acid with the resin (PS-DCC and PS-EDC). Finally, positive results were obtained with the use of PS-1-hydroxybenzotriazole (PS-HOBt). Thus, protected gallic acid 55 or $\mathbf{5 6}$ was loaded on the resin in the presence of diisopropylcarbodiimide (DIC) and DMAP, and the resulting activated acid $\mathbf{5 7}$ or $\mathbf{5 8}$ linked to the resin was filtered, washed and dried (Scheme 1, Method A). It is important to note that this intermediate can be stored at least one month at $4{ }^{\circ} \mathrm{C}$, without significant reactivity loss. In a second step, the reaction of $\mathbf{5 7}$ or $\mathbf{5 8}$ with the corresponding diol in the presence of diisopropylethylamine (DIEA) afforded all protected target esters except 38, 39, 46, and $\mathbf{5 0}$ that could not be obtained using this PS-based methodology possibly due to steric hindrance. Therefore, 
they were synthesized by classical condensation reaction between the corresponding acyl chloride $\mathbf{5 9}$ or $\mathbf{6 0}^{21}$ and the adequate diol in the presence of triethylamine (TEA) (Scheme 1, Method B). Final removal of the protecting groups either by catalytic hydrogenation (in the case of benzyl groups) or by treatment with a hydrofluoride acid-pyridine (HF-py) complex (for the TBS-protected intermediates) afforded the desired final compounds 5-30. In the case of benzyl intermediates 43 and 44, in which the A subunit is naphthalene, catalytic hydrogenation for 3 to 5 h gave naphthalene compounds $\mathbf{2 0}$ and $\mathbf{2 1}$, respectively, whereas exhaustive hydrogenation overnight afforded tetrahydronaphthalene analogues $\mathbf{1 7}$ and 18, respectively.

The synthesis of the starting carboxylic acid $\mathbf{5 5}^{22}$ involved the perbenzylation of the commercial methyl gallate followed by saponification of the ester, whereas $\mathbf{5 6}^{23}$ was obtained by reaction of gallic acid with tert-butyldimethylsilyl chloride (TBSCl) and subsequent selective cleavage of the silyl ester. Non-commercial intermediate diols trans- and cis-1,2,3,4-tetrahydronaphthalene-1,4-diol, ${ }^{24}$ naphthalene-1,2-diol, ${ }^{25}$ methyl 1,4-dihydroxy-2-naphthoate, ${ }^{26}$ and naphthalene-1,8-diol ${ }^{27}$ were obtained following previously described procedures.

Cytotoxicity in SK-Br3 cells. All the new final compounds were first screened for their in vitro cytotoxic activity against SK-Br3 human breast cancer cell line, selected because of its high FASN expression. The $\mathrm{IC}_{50}$ values are shown in Table 1, where the reference compound $\mathbf{4}$ has also been included for comparative purposes. These data have allowed us to carry out a SAR study on the influence of the modifications of the A subunit in the cytotoxic capacity of the compounds. The main conclusions can be summarized as follows: (i) Most of the final compounds are highly cytotoxic in SKBr3 cells $\left(\mathrm{IC}_{50}<50 \mu \mathrm{M}\right)$, being more potent than $4\left(\mathrm{IC}_{50}=149 \pm 20 \mu \mathrm{M}\right)$; (ii) in general, the presence of at least one aromatic ring in the A subunit is required for cytotoxicity, as suggested by derivatives 5-7, inactive in $\mathrm{SK}-\mathrm{Br} 3$ cells $\left(\mathrm{IC}_{50}>150 \mu \mathrm{M}\right)$; (iii) for those compounds where the A subunit is a phenyl ring (8-14), cytotoxicity increases as the distance between the two galloyl moieties augments. Thus, all the compounds with a relative 1,4-substitution in the phenyl ring show lower $\mathrm{IC}_{50}$ values than analogs $\mathbf{8}$ and 9 (with 1,2- and 1,3-substitution, respectively). Among them, derivative 14 deserves special attention as 
being the most cytotoxic one $\left(\mathrm{IC}_{50}=8 \mu \mathrm{M}\right)$; (iv) replacement of the benzene ring in the A subunit for different tetrahydronaphthalenes (derivatives 15-18) did not yield any significant improvement in cytotoxicity, with compounds showing $\mathrm{IC}_{50}$ values between 22 and $42 \mu \mathrm{M}$; (v) introduction of a naphthalene ring as A subunit (compounds 19-29) yielded some interesting derivatives with good cytotoxicity values. Among them, polyphenols 20, 23, 28 and 29 with $\mathrm{IC}_{50}$ values between 5 and $26 \mu \mathrm{M}$, deserve special attention. Importantly, this naphthalene series suggests that, as observed for benzene derivatives 8-14, cytotoxicity increases as the distance between the galloyl moieties augments, being 28 the most potent compound (relative 2,6-orientation of galloyl groups and $\mathrm{IC}_{50}=5 \mu \mathrm{M}$ ), and compounds 19, 26 and 27 the less active ones (relative 1,2-, 1,8- and 2,3-orientation of galloyl groups, and $\mathrm{IC}_{50}$ values of 74,78 and $76 \mu \mathrm{M}$, respectively). These data prompted us to introduce a biphenyl system as A subunit with the two galloyl groups as distant as possible (i.e. in a relative 4,4'-position, see Table 1). This modification led to the identification of analog $\mathbf{3 0}$, the most potent derivative in the series in terms of cytotoxicity, with an $\mathrm{IC}_{50}$ value of $4 \mu \mathrm{M}$.

FASN inhibition. Considering our objective of identifying FASN inhibitors with antitumor properties, those compounds that inhibited more effectively the proliferation of the $\mathrm{SK}-\mathrm{Br} 3$ cells $\left(\mathrm{IC}_{50}\right.$ value lower than $50 \mu \mathrm{M}$ ) were assessed for their capacity to block FASN activity. Towards this end, SK$\mathrm{Br} 3$ cells were incubated for $24 \mathrm{~h}$ in the presence of a concentration of the compound equal to its cytotoxic $\mathrm{IC}_{50}$ value in these cells, and FASN activity was measured in particle-free supernatants. The inhibition is expressed as the percentage of inactivation compared to a $100 \%$ activity control sample (Table 1). The obtained results show that some of the cytotoxic compounds $(\mathbf{1 3}, \mathbf{1 6}, \mathbf{2 0}, \mathbf{2 1}, \mathbf{2 3}, \mathbf{2 7}$ and 30) are indeed FASN inhibitors able to block between the $30 \%$ and the $90 \%$ of its total activity. Among them, derivatives $\mathbf{2 0}$ and $\mathbf{3 0}$ stand out as being not only highly cytotoxic in $\mathrm{SK}-\mathrm{Br} 3$ cells $\left(\mathrm{IC}_{50}\right.$ values of 21 and $4 \mu \mathrm{M}$, respectively) but also the most potent FASN inhibitors identified within the series $(90 \%$ of FASN inhibition, Table 1). Prompted by these results, we previously disclosed the pharmacological profile of derivative 20, which turned out to induce apoptosis in SK-Br3 cells without affecting CPT-1 
activity. ${ }^{20}$ Considering that both $\mathbf{2 0}$ and $\mathbf{3 0}$ block FASN activity in a similar extent (up to 90\%) but $\mathbf{3 0}$ does it at a five-fold lower concentration ( $21 \mu \mathrm{M}$ for $\mathbf{2 0} v s 4 \mu \mathrm{M}$ for $\mathbf{3 0}$ ), this latter compound is clearly worthy of an in-depth pharmacological study since it could be a good tool-compound for ensuing in vivo studies and validation of FASN as a target with therapeutic interest. Among the obtained results it is important to note that compound $\mathbf{2 8}$ had a cytotoxic potency in SK-Br3 cells comparable to compound 30 but did not inhibit FASN significantly (Table 1), which suggests that there are additional mechanisms apart from inhibition of FASN activity that may derive in cytotoxic effects. Conversely, an effect of derivative $\mathbf{3 0}$ on an additional target different from FASN cannot be ruled out. Accordingly, we sought to rule out general cytotoxicity of compound $\mathbf{3 0}$ and to confirm that FASN was the main mechanism mediating the cell death induced by this derivative. With respect to the former, we determined the capacity of compound $\mathbf{3 0}$ to inhibit cell proliferation in non cancer human mammary epithelial HMEpC and hepatic HL-7702 cells. In both cell lines, derivative $\mathbf{3 0}$ induced little cytotoxicity, with $\mathrm{IC}_{50}$ values from eight to ten-fold higher than in SK-Br3 cells $\left[\mathrm{IC}_{50}(\mathbf{3 0}, \mathrm{SK}-\mathrm{Br} 3)=4 \mu \mathrm{M} ; \mathrm{IC}_{50}(\mathbf{3 0}, \mathrm{HMEpC})=31\right.$ $\left.\mu \mathrm{M} ; \mathrm{IC}_{50}(\mathbf{3 0}, \mathrm{HL}-7702)=41 \mu \mathrm{M}\right]$. To study the actual contribution of FASN to the cytotoxic effects, its expression was knocked down in SK-Br3 cells using a FASN specific siRNA and cellular viability was determined in parallel for transfected and non-transfected cells. Our results show that decreasing FASN expression in an $80 \%$ (quantified by western blot band intensity densitometry) eliminates the cytotoxicity of compound 30, which does not induce any significant cell death up to a concentration of $10 \mu \mathrm{M}$ (Figure 1). Hence, derivative 30 was selected for a comprehensive biological characterization including the study of its cytotoxicity in a panel of different tumor cell lines, its molecular mechanism of action as well as its selectivity vs CPT-1 enzyme.

Cytotoxicity of FASN inhibitor 30 in a panel of tumor cells. The capacity of derivative 30 to induce cytotoxicity was further evaluated in a panel comprising a variety of tumor cells of different tissue origins, including colon, pancreas, skin, liver, ovary, breast, and lung. The $\mathrm{IC}_{50}$ values obtained for the different cell lines are shown in Table 2. In general, compound $\mathbf{3 0}$ showed a remarkable cytotoxicity in the tumor cell line panel, being especially relevant its potency in the HCT116, PANC-1, A431, SKOV3, 
MCF-7, ZR-75-1, MDA-MB-231, and H460 cells in which the $\mathrm{IC}_{50}$ values were below $10 \mu \mathrm{M}$. In general, breast cancer cells with high FASN levels, such as SK-Br3, MCF-7, ZR-75-1, and MDA-MB231 cells (Figure 2A), are more sensitive to compound 30, with $\mathrm{IC}_{50}$ values between 2 and $5 \mu \mathrm{M}$ (Table 2). Lower FASN levels decrease the sensitivity of cells towards compound 30, as observed in BT-20 and AU565 breast cancer cell lines ( $\mathrm{IC}_{50}$ values of 17 and $24 \mu \mathrm{M}$, respectively, Table 2 and Figure 2A). This correlation between FASN levels and cytotoxicity of derivative $\mathbf{3 0}$ is also observed in the hepatic cancer cells Bel-7402, SK-Hep1 and HepG2 (Figure 2B) with $\mathrm{IC}_{50}$ values of 40, 56 and $70 \mu \mathrm{M}$, respectively (Table 2). Taken together, these results clearly support the potential of the new FASN inhibitor $\mathbf{3 0}$ as an antitumor compound of wide application and prompted us to gain insights on the cell death mechanism and molecular pathways involved in this effect.

Cell death mechanism and signaling pathways. In order to establish the mechanism of action of compound 30, we first evaluated whether it induced apoptosis and caspase activity by western blotting analysis showing cleavage of poly(ADP-ribose) polymerase (PARP). Treatment of SK-Br3 cells for $48 \mathrm{~h}$ induced a marked increase in the levels of the PARP cleavage product ( $89 \mathrm{kDa}$ band) in a timedependent manner (Figure 3A). In the light of the previously reported effect of FASN inhibitors not only in apoptosis but also in the HER2 receptor and its associated pathways, ${ }^{17,20,28}$ we assessed the effects of 30 on HER2 activation as well as on its downstream signal transduction pathways ERK1/2 and $\mathrm{PI} 3 \mathrm{~K} / \mathrm{AKT}$. Incubation of cells with $\mathbf{3 0}$ dramatically decreased the levels of the phosphorylated form of HER2 (p-HER2), that occurred as soon as $2 \mathrm{~h}$ after treatment (data not shown), and became complete at $6 \mathrm{~h}$ after treatment (Figure 3B). During this period, there was no significant change in the total level of HER2 protein, as assessed by either western blotting analysis (Figure 3B) or HER2-specific ELISA (data not shown). Phosphorylated forms of ERK1/2 (p-ERK1/2) and AKT (p-AKT) were also noticeably decreased after $6 \mathrm{~h}$ of exposure to compound $\mathbf{3 0}$ (Figure 3B). Overall, the derivative $\mathbf{3 0}$ induced a sustained blockade of the HER2 signaling pathway, at least throughout the whole time interval analyzed (24 h). During this period, no significant changes in the total level of the corresponding proteins (HER2, AKT, and ERK1/2) were detected. Remarkably, under the same culture conditions, EGCG did not 
induce apoptosis nor blocked the activation of HER2 oncogene and its downstream signal transduction pathways, ERK1/2 and PI3K/AKT. ${ }^{20}$

CPT-1 activation and in vivo weight loss. Given the importance of inhibition of FASN without a cross-activation of CPT-1, which is relevant to avoid the side effect of weight loss, compound $\mathbf{3 0}$ was analyzed both in vitro and in mice. Importantly, 30 did not stimulate CPT-1 activity (Figure 4A), in a similar manner to what it had been previously described for the natural FASN inhibitor $\mathbf{4}$ and in sharp contrast to compound $\mathbf{2}$ which, as previously reported, produced a significant activation of CPT-1 activity. Both reference FASN inhibitors 2 and $\mathbf{4}$ are included in Figure 4A for comparative purposes. Consistently with these in vitro results, healthy mice treated with a single intraperitoneal (i.p.) dose of 30,50 or $75 \mathrm{mg} / \mathrm{kg}$ of compound $\mathbf{3 0}$ did not show any significant weight loss $v s$ the control group (Figure 4B). Food intake was similar to controls and altered behavior or signs of suffering or distress were not observed in mice treated with $\mathbf{3 0}$ (data not shown). These effects are especially significant when compared with animals treated with a $30 \mathrm{mg} / \mathrm{kg}$ i.p. dose of $\mathbf{2}$, in which a $21 \%$ weight loss, as well as signs of suffering, were observed. Altogether, our findings indicate that the new synthetic FASN inhibitor $\mathbf{3 0}$ does not induce weight loss in vivo.

\section{Conclusion}

In this work we report the synthesis of a new series of polyphenolic derivatives that have been evaluated for their cytotoxic capacity in SK-Br3 cells, a human breast cancer cell line with high FASN expression. The most cytotoxic compounds have been further assessed as FASN inhibitors. Among them, derivative $\mathbf{3 0}$ stands out as a potent FASN inhibitor which blocks the $90 \%$ of FASN activity at low concentration $(4 \mu \mathrm{M})$ and is highly cytotoxic in a broad panel of tumor cells of different tissue origins, with $\mathrm{IC}_{50}$ values below $10 \mu \mathrm{M}$. At the molecular level, compound $\mathbf{3 0}$ induces apoptosis of tumor cells and blocks activation of the HER2 receptor and its downstream proteins AKT and ERK1/2. Importantly, these effects occur without parallel CPT-1 stimulation or in vivo weight loss. Overall, our 
results clearly indicate that compound $\mathbf{3 0}$ is a promising new FASN inhibitor that could contribute to the validation of this enzyme as a therapeutic target for the treatment of different types of cancer.

\section{Experimental Section}

Chemistry. Melting points (mp, uncorrected) were determined on a Stuart Scientific electrothermal apparatus. Infrared (IR) spectra were measured on a Shimadzu-8300 or Bruker Tensor 27 instrument equipped with a Specac ATR accessory of 5200-650 $\mathrm{cm}^{-1}$ transmission range; frequencies $(v)$ are expressed in $\mathrm{cm}^{-1}$. Nuclear Magnetic Resonance (NMR) spectra were recorded on a Bruker Avance 300$\mathrm{AM}\left({ }^{1} \mathrm{H}, 300 \mathrm{MHz} ;{ }^{13} \mathrm{C}, 75 \mathrm{MHz}\right)$ or Bruker $200-\mathrm{AC}$ spectrometer $\left({ }^{1} \mathrm{H}, 200 \mathrm{MHz} ;{ }^{13} \mathrm{C}, 50 \mathrm{MHz}\right)$ at the UCM's NMR facilities. Chemical shifts $(\delta)$ are expressed in parts per million relative to internal tetramethylsilane; coupling constants $(J)$ are in hertz $(\mathrm{Hz})$. The following abbreviations are used to describe peak patterns when appropriate: s (singlet), d (doublet), t (triplet), m (multiplet), br (broad). Mass spectrometry (MS) was carried out on a Bruker LC-Esquire in electrospray mode (ESI). High Pressure Liquid Chromatography-Mass Spectrometry (HPLC-MS) analysis was performed using an Agilent 1200LC-MSD VL. LC separation was achieved with an Eclipse XDB-C18 column (5 $\mu$, 4.6 $\mathrm{mm} \times 150 \mathrm{~mm})$ together with a guard column $(5 \mu \mathrm{m}, 4.6 \mathrm{~mm} \times 12.5 \mathrm{~mm})$. The gradient mobile phases consisted of A (95:5 water/MeOH) and $\mathrm{B}(5: 95$ water $/ \mathrm{MeOH})$ with $0.1 \%$ ammonium hydroxide and $0.1 \%$ formic acid as the solvent modifiers. MS analysis was performed with an ESI source. The capillary voltage was set to $3.0 \mathrm{kV}$ and the fragmentor voltage was set at $72 \mathrm{eV}$. The drying gas temperature was $350{ }^{\circ} \mathrm{C}$, the drying gas flow was $10 \mathrm{~L} / \mathrm{min}$, and the nebulizer pressure was 20 psi. Spectra were acquired in negative ionization mode from 200 to $800 \mathrm{~m} / \mathrm{z}$ and in UV-mode at four different wavelengths (210, 230, 254, and $280 \mathrm{~nm})$. Satisfactory HPLC-MS traces confirmed a purity of at least $95 \%$ for all tested compounds and their retention times are provided on the supporting information. Hydrogenations were carried out in a Parr Hydrogenator under an initial pressure of hydrogen of 40-50 psi at room temperature for $1 \mathrm{~h}$. Analytical thin-layer chromatography (TLC) was run on Merck silica gel plates (Kieselgel 60 F-254) with detection by UV light (254 nm), ninhydrin solution, or 10\% phosphomolybdic 
acid solution in ethanol. Flash chromatography was performed on glass column using silica gel type 60 (Merck, particle 230-400 mesh) or on a Varian 971-FP flash purification system using silica gel cartridges (Varian, particle size $50 \mu \mathrm{m}$ ). Unless stated otherwise, starting materials, reagents and solvents were purchased as high-grade commercial products from Sigma-Aldrich, Lancaster, Scharlab or Panreac, and were used without further purification. Tetrahydrofuran (THF) was distilled from sodium benzophenone ketyl and used immediately. Dichloromethane (DCM) was distilled from calcium hydride.

Compounds $55,,^{22} 56,{ }^{23} 59,{ }^{21}$ and $60^{21}$ were synthesized according to described procedures, and their spectroscopic data are in agreement with those previously reported. Spectral characterization data of all described compounds were consistent with the proposed structures. Satisfactory HPLC chromatograms were also obtained for final compounds 5-30. We include here the data of protected esters $\mathbf{3 9}, \mathbf{4 0}$, and 53, and final compounds 16, 17, 23, 29, and 30. All other compounds are fully characterized in the Supporting Information.

General procedure for the preparation of the resin-bound intermediates 57 and 58 . According to a previously optimized methodology, ${ }^{29}$ the following anhydrous DCM solutions were sequentially added to one equiv of PS-HOBt: 0.6 equiv of DMAP in $20 \mathrm{~mL} / \mathrm{mmol}, 1.5$ equiv of $\mathbf{5 5}$ or $\mathbf{5 6}$ in $2.5 \mathrm{~mL} / \mathrm{mmol}$, and 4.4 equiv of DIC in $0.6 \mathrm{~mL} / \mathrm{mmol}$. The reaction was stirred under an argon atmosphere at room temperature for $3 \mathrm{~h}$ and the resulting solid was filtered and washed with DMF, DCM, and THF. The residue was dried under vacuum to give $\mathbf{5 7}$ or $\mathbf{5 8}$ in quantitative yield.

3,4,5-Tris(benzyloxy)benzoic acid bound to PS-HOBt (57) was prepared from $475 \mathrm{mg}$ of PS-HOBt, $39 \mathrm{mg}$ of DMAP dissolved in $6.4 \mathrm{~mL}$ of DCM, $350 \mathrm{mg}$ of $\mathbf{5 5}$ dissolved in $2.0 \mathrm{~mL}$ of DCM and $1.2 \mathrm{~mL}$ of DMF, and $0.36 \mathrm{~mL}$ of DIC dissolved in $1.4 \mathrm{~mL}$ DCM.

3,4,5-Tris(tert-butyldimethylsilyloxy)benzoic acid bound to PS-HOBt (58) was prepared from 150 $\mathrm{mg}$ of PS-HOBt, $12 \mathrm{mg}$ of DMAP dissolved in $2 \mathrm{~mL}$ of DCM, $128 \mathrm{mg}$ of $\mathbf{5 6}$ dissolved in $0.6 \mathrm{~mL}$ of DCM and $0.3 \mathrm{~mL}$ of DMF, and $0.11 \mathrm{~mL}$ of DIC dissolved in $0.44 \mathrm{~mL}$ DCM. 
General procedure for the synthesis of protected esters 31-37, 40-45, 47-49, and 51-54 (Method A). A suspension of 57 or 58 (2.14 equiv), the adequate diol (1 equiv) and DIEA (2.86 equiv) in anhydrous THF $(20 \mathrm{~mL} / \mathrm{mmol}$ of diol) was stirred at room temperature under an argon atmosphere overnight. The reaction mixture was filtered through a plug of silica gel, washed with saturated $\mathrm{NH}_{4} \mathrm{Cl}$, water and brine, dried over $\mathrm{Na}_{2} \mathrm{SO}_{4}$ and evaporated under vacuum. The title compound was obtained as a white solid and was used in the following reaction without further purification.

1,2-Bis([3,4,5-tris(benzyloxy)benzoyl]oxy)ethane (31) was prepared from 57 and ethylene glycol. Yield $71 \%$.

cis-1,2-Bis([3,4,5-tris(benzyloxy)benzoyl]oxy)cyclohexane (32) was prepared from 57 and ciscyclohexane-1,2-diol. Yield 64\%.

trans-1,2-Bis([3,4,5-tris(benzyloxy)benzoyl]oxy)cyclohexane (33) was prepared from $\mathbf{5 7}$ and transcyclohexane-1,2-diol. Yield 50\%.

1,2-Bis([3,4,5-tris(benzyloxy)benzoyl]oxy)benzene (34) was prepared from 57 and cathechol. Yield $37 \%$.

1,3-Bis([3,4,5-tris(benzyloxy)benzoyl]oxy)benzene (35) was prepared from 57 and resorcinol. Yield $68 \%$.

1,4-Bis([3,4,5-tris(benzyloxy)benzoyl]oxy)benzene (36) was prepared from 57 and hydroquinone. Yield 24\%.

2-Methyl-1,4-bis([3,4,5-tris(benzyloxy)benzoyl]oxy)benzene (37) was prepared from 57 and 2methylbenzene-1,4-diol. Yield 52\%.

2-Methoxy-1,4-bis([3,4,5-tris(benzyloxy)benzoyl]oxy)benzene (40) was prepared from 57 and 2methoxybenzene-1,4-diol. Yield 30\%; mp 197-198 ${ }^{\circ} \mathrm{C}$; IR (KBr) v 1735, 1585, 1506, 1115; ${ }^{1} \mathrm{H}$ NMR $\left(200 \mathrm{MHz}, \mathrm{CDCl}_{3}\right) \delta 3.90\left(\mathrm{~s}, 3 \mathrm{H}, \mathrm{CH}_{3}\right), 5.24\left(\mathrm{~s}, 4 \mathrm{H}, 4 \mathrm{CH}_{2} \mathrm{Bn}\right), 5.26\left(\mathrm{~s}, 8 \mathrm{H}, 4 \mathrm{CH}_{2} \mathrm{Bn}\right)$, 6.88-6.96 (m, 2H, benzene), $7.25(\mathrm{~d}, J=8.4,1 \mathrm{H}$, benzene), 7.34-7.57 (m, 30H, Bn), $7.62(\mathrm{~s}, 2 \mathrm{H}$, gal), 7.65 (s, 2H, gal); ${ }^{13} \mathrm{C}$ NMR $\left(50 \mathrm{MHz}, \mathrm{CDCl}_{3}\right) \delta 56.1\left(\mathrm{CH}_{3}\right), 71.2,71.3\left(4 \mathrm{CH}_{2}\right), 75.1\left(2 \mathrm{CH}_{2}\right), 106.8(\mathrm{CH}), 109.7,109.8$ (4CH), 113.5, $123.1(2 \mathrm{CH}), 124.2(2 \mathrm{C}), 127.5,127.6,128.0,128.2,128.5(30 \mathrm{CH}), 136.5,137.3,137.4$, 
137.6 (7C), 143.0, 143.1, 149.3, 151.9 (4C), 152.6, 152.7 (4C), 164.1, 164.5 (2C=O); ESI-MS 1007.1 $(\mathrm{M}+\mathrm{Na})^{+}$.

cis-1,4-Bis [(3,4,5-tris(tert-butyldimethylsilyloxy)benzoyl)oxy]-1,2,3,4-tetrahyd ronaphthalene (41) was prepared from 58 and cis-1,2,3,4-tetrahydronaphthalene-1,4-diol. Yield 20\%.

trans-1,4-Bis[(3,4,5-tris(tert-butyldimethylsilyloxy)benzoyl)oxy]-1,2,3,4-tetrahyd ronaphthalene

(42) was prepared from 58 and trans-1,2,3,4-tetrahydronaphthalene-1,4-diol. Yield 53\%.

1,3-Bis([3,4,5-tris(benzyloxy)benzoyl]oxy)naphthalene (43) was prepared from 57 and naphthalene1,3-diol. Yield 47\%.

1,4-Bis([3,4,5-tris(benzyloxy)benzoyl]oxy)naphthalene (44) was prepared from 57 and naphthalene1,4-diol. Yield 64\%.

1,2-Bis[(3,4,5-tris(tert-butyldimethylsilyloxy)benzoyl)oxy]naphthalene (45) was prepared from 58 and naphthalene-1,2-diol. Yield 60\%.

1,5-Bis([3,4,5-tris(benzyloxy)benzoyl]oxy)naphthalene (47) was prepared from 57 and naphthalene1,5-diol. Yield 42\%.

1,6-Bis $[(3,4,5$-tris(tert-butyldimethylsilyloxy)benzoyl)oxy]naphthalene (48) was prepared from 58 and naphthalene-1,6-diol. Yield 24\%.

1,7-Bis $[(3,4,5$-tris(tert-butyldimethylsilyloxy)benzoyl)oxy]naphthalene (49) was prepared from 58 and naphthalene-1,7-diol. Yield 24\%.

2,3-Bis([3,4,5-tris(benzyloxy)benzoyl]oxy)naphthalene (51) was prepared from 57 and naphthalene2,3-diol. Yield 37\%.

2,6-Bis([3,4,5-tris(benzyloxy)benzoyl]oxy)naphthalene (52) was prepared from 57 and naphthalene2,6-diol. Yield 39\%.

2,7-Bis [(3,4,5-tris(tert-butyldimethylsilyloxy)benzoyl)oxy]naphthalene (53) was prepared from 58 and naphthalene-2,7-diol. Yield 39\%; mp 66-67 ${ }^{\circ} \mathrm{C}$; IR (neat) v 1741, 1578, 1082; ${ }^{1} \mathrm{H}$ NMR $(300 \mathrm{MHz}$, $\left.\mathrm{CDCl}_{3}\right) \delta 0.19\left(\mathrm{~s}, 12 \mathrm{H}, 2 \mathrm{Me}_{2} \mathrm{SiO}\right), 0.29\left(\mathrm{~s}, 24 \mathrm{H}, 4 \mathrm{Me}_{2} \mathrm{SiO}\right), 0.99(\mathrm{~s}, 36 \mathrm{H}, 4 t-\mathrm{BuSiO}), 1.03(\mathrm{~s}, 18 \mathrm{H}, 2 t-$ BuSiO), 7.36 (dd, $J=8.9,2.2,2 \mathrm{H}$, naph), 7.42 (s, 4H, gal), 7.67 (d, $J=2.2,2 \mathrm{H}$, naph,), 7.92 (d, $J=7.9$, 
$2 \mathrm{H}$, naph); ${ }^{13} \mathrm{C} \mathrm{NMR}\left(75 \mathrm{MHz}, \mathrm{CDCl}_{3}\right) \delta-3.9,-3.6\left(12 \mathrm{CH}_{3}\right), 18.5,18.8(6 \mathrm{C}), 26.1,26.2\left(18 \mathrm{CH}_{3}\right), 116.1$ (4CH), 118.4 (2CH), $121.1(2 \mathrm{C}), 121.2,129.1(4 \mathrm{CH}), 129.3,134.4(2 \mathrm{C}), 144.0,148.7$ (6C), 149.5 (2C), $164.8(2 \mathrm{C}=\mathrm{O})$; ESI-MS $1171.6(\mathrm{M}+\mathrm{Na})^{+}$.

4,4'-Bis([3,4,5-tris(benzyloxy)benzoyl]oxy)-1,1'-biphenyl (54) was prepared from 57 and 1,1'biphenyl-4,4'-diol. Yield 77\%.

General procedure for the synthesis of protected esters 38, 39, 46, and 50 (Method B). To a solution of 59 or $\mathbf{6 0}$ (2.2 equiv) and TEA (2.2 equiv) in anhydrous THF $(10 \mathrm{~mL} / \mathrm{mmol})$, the corresponding diol (1 equiv) dissolved in THF $(2 \mathrm{~mL} / \mathrm{mmol})$ was added. The reaction was stirred under an argon atmosphere at room temperature overnight. Afterwards, the reaction mixture was washed with saturated $\mathrm{NaHCO}_{3}$, dried over $\mathrm{Na}_{2} \mathrm{SO}_{4}$ and evaporated under reduced pressure. The residue was purified by column chromatography using the appropriate eluent to give pure title compound as a white solid.

2,5-Bis([3,4,5-tris(benzyloxy)benzoyl]oxy)-1,1'-biphenyl (38) was prepared from 59 and 1,1'biphenyl-2,5-diol. Chromatography DCM/hexane 7:3 ( $\left.\mathrm{R}_{\mathrm{f}} 0.26\right)$; yield 57\%.

Methyl 2,5-bis[(3,4,5-tris(tert-butyldimethylsilyloxy)benzoyl)oxy]benzoate (39) was prepared from 60 and methyl 2,5-dihydroxybenzoate. Chromatography DCM/hexane 2:8 $\left(\mathrm{R}_{\mathrm{f}}\right.$ 0.27, DCM/hexane 4:6); yield 53\%; mp 191-192 ${ }^{\circ} \mathrm{C}$; IR (neat) $v 1741,1576,1081 ;{ }^{1} \mathrm{H}$ NMR $\left(300 \mathrm{MHz}, \mathrm{CDCl}_{3}\right) \delta 0.18(\mathrm{~s}, 12 \mathrm{H}$, $\left.2 \mathrm{Me}_{2} \mathrm{SiO}\right), 0.28\left(\mathrm{~s}, 24 \mathrm{H}, 4 \mathrm{Me}_{2} \mathrm{SiO}\right), 0.98$ (s, 36H, 2t-BuSiO), 1,02 (s, 18H, 2t-BuSiO), 3.73 (s, 3H, $\left.\mathrm{CH}_{3}\right), 7.28(\mathrm{~d}, J=8.9,1 \mathrm{H}$, benzene), 7.38 (s, 2H, gal), $7.41(\mathrm{~s}, 2 \mathrm{H}$, gal), 7.45 (dd, $J=8,7,2,9,1 \mathrm{H}$, benzene), $7.89\left(\mathrm{~d}, J=2.8,1 \mathrm{H}\right.$, benzene); ${ }^{13} \mathrm{C} \mathrm{NMR}\left(75 \mathrm{MHz}, \mathrm{CDCl}_{3}\right) \delta-3.5,-3.4,-3.2\left(12 \mathrm{CH}_{3}\right), 18.9$, 19.2 (6C), 26.5, $26.6\left(18 \mathrm{CH}_{3}\right), 52.6\left(\mathrm{CH}_{3}\right), 116.5,116.7(4 \mathrm{CH}), 121.1,121.4(2 \mathrm{C}), 124.9(\mathrm{C}), 125.3$, $125.4,127.4(3 \mathrm{CH}), 144.4,144.6(2 \mathrm{C}), 148.6,148.7(2 \mathrm{C}), 149.0,149.1(4 \mathrm{C}), 164.8,164.9,165.4$ $(3 \mathrm{C}=\mathrm{O})$; ESI-MS (ESI) $1179.6(\mathrm{M}+\mathrm{Na})^{+}$.

Methyl 1,4-bis[(3,4,5-tris(tert-butyldimethylsilyloxy)benzoyl)oxy]-2-naphthoate (46) was prepared from 60 and methyl 1,4-dihydroxy-2-naphthoate. Chromatography DCM/hexane 2:8 $\left(\mathrm{R}_{\mathrm{f}} 0.42\right)$; yield $41 \%$. 
1,8-Bis $[(3,4,5$-tris(tert-butyldimethylsilyloxy)benzoyl)oxy]naphthalene (50) was prepared from 60 and naphthalene-1,8-diol. Chromatography DCM/hexane 1:1 $\left(\mathrm{R}_{\mathrm{f}} 0.24\right)$; yield 24\%.

General procedure for the synthesis of final compounds 5-12, 14, 17, 18, 20, 21, 23, 27, 28, and 30. To a solution of benzyl derivative 31-38, 40, 43, 44, 47, 51, 52, or 54 in a mixture of DCM/ethanol (270 $\mathrm{mL} / \mathrm{mmol}), 20 \% \mathrm{Pd}(\mathrm{OH})_{2}$ on carbon $(980 \mathrm{mg} / \mathrm{mmol})$ was added, and the mixture was hydrogenated (initial hydrogen pressure: $50 \mathrm{psi}$ ) at room temperature for 3 to $5 \mathrm{~h}$ or overnight (for compounds $\mathbf{1 7}$ and 18). Then, the catalyst was filtered, the solvents were evaporated under reduced pressure, and the resulting solid was recrystallized from DCM/methanol, to afford pure title compound.

1,2-Bis[(3,4,5-trihydroxybenzoyl)oxy]ethane (5) was prepared from intermediate 31. Yield 95\%.

cis-1,2-Bis $[(3,4,5$-trihydroxybenzoyl)oxy]cyclohexane (6) was prepared from intermediate 32. Yield $70 \%$.

trans-1,2-Bis[(3,4,5-trihydroxybenzoyl)oxy]cyclohexane (7) was prepared from intermediate 33. Yield 75\%.

1,2-Bis $[(3,4,5$-trihydroxybenzoyl)oxy $]$ benzene $(\mathbf{8})$ was prepared from intermediate 34 . Yield 60\%. 1,3-Bis $[(3,4,5$-trihydroxybenzoyl)oxy]benzene (9) was prepared from intermediate 35 . Yield 60\%.

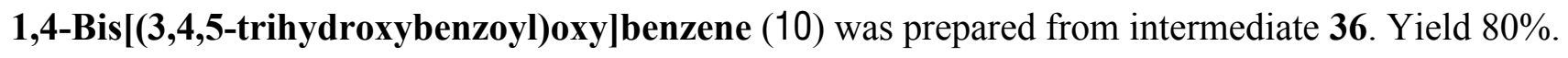
2-Methyl-1,4-bis[(3,4,5-trihydroxybenzoyl)oxy]benzene (11) was prepared from intermediate 37. Yield $67 \%$.

2,5-Bis[(3,4,5-trihydroxybenzoyl)oxy]-1,1'-biphenyl (12) was prepared from intermediate 38. Yield $75 \%$.

2-Methoxy-1,4-bis[(3,4,5-trihydroxybenzoyl)oxy]benzene (14) was prepared from intermediate 40. Yield 77\%.

1,3-Bis[(3,4,5-trihydroxybenzoyl)oxy]-5,6,7,8-tetrahydronaphthalene (17) was prepared from intermediate 43. Yield 92\%; $\mathrm{mp} 213{ }^{\circ} \mathrm{C}$ (dec); IR (neat) v 3356, 1705, 1615, 1200; ${ }^{1} \mathrm{H}$ NMR (200 MHz, $\left.\mathrm{CD}_{3} \mathrm{OD}\right) \delta 1.80(\mathrm{~m}, 4 \mathrm{H}$, tetrahydronaph), $2.59(\mathrm{~m}, 2 \mathrm{H}$, tetrahydronaph), $2.83(\mathrm{~m}, 2 \mathrm{H}$, tetrahydronaph), $6.78(\mathrm{~d}, J=2.3,1 \mathrm{H}$, tetrahydronaph), $6.84(\mathrm{~d}, J=2.3,1 \mathrm{H}$, tetrahydronaph), $7.18(\mathrm{~s}, 2 \mathrm{H}$, gal $), 7.21(\mathrm{~s}$, 
$2 \mathrm{H}$, gal $) ;{ }^{13} \mathrm{C} \mathrm{NMR}\left(50 \mathrm{MHz}, \mathrm{CD}_{3} \mathrm{OD}\right) \delta 23.6,23.8,24.3,30.6\left(4 \mathrm{CH}_{2}\right), 110.7(4 \mathrm{CH}), 114.4(\mathrm{CH}), 120.4$, $120.6(2 \mathrm{C}), 120.8(\mathrm{CH}), 128.4(\mathrm{C}), 140.6,140.7,141.1$ (3C), 146.7, 146.8 (4C), 150.3, 151.0 (2C), 166.6, $167.0(2 \mathrm{C}=\mathrm{O})$; ESI-MS $466.9(\mathrm{M}-\mathrm{H})^{-}$.

1,4-Bis $[(3,4,5-t r i h y d r o x y b e n z o y l) o x y]-5,6,7,8$-tetrahydronaphthalene (18) was prepared from intermediate 44 . Yield $88 \%$.

1,3-Bis $[(3,4,5-t r i h y d r o x y b e n z o y l) o x y]$ naphthalene (20) was prepared intermediate 43 . Yield 65\%.

1,4-Bis[(3,4,5-trihydroxybenzoyl)oxy]naphthalene (21) was prepared from intermediate 44 . Yield $88 \%$.

1,5-Bis[(3,4,5-trihydroxybenzoyl)oxy]naphthalene (23) was prepared from intermediate 47 . Yield $30 \%$; mp $265^{\circ} \mathrm{C}(\mathrm{dec})$; IR (KBr) v 3404, 1718, 1618, 1209; ${ }^{1} \mathrm{H}$ NMR $\left(300 \mathrm{MHz}, \mathrm{CD}_{3} \mathrm{OD}\right) \delta 7.35(\mathrm{~s}, 4 \mathrm{H}$, gal), 7.40 (d, $J=7.5,2 \mathrm{H}$, naph), 7.58 (t, $J=7.9,2 \mathrm{H}$, naph), $7.84\left(\mathrm{~d}, J=8.2,2 \mathrm{H}\right.$, naph); ${ }^{13} \mathrm{C}$ NMR $(50$ MHz, DMSO- $\left.d_{6}\right) \delta 109.2(4 \mathrm{CH}), 117.5(2 \mathrm{CH}), 119.3(2 \mathrm{C}), 127.6,127.8(4 \mathrm{CH}), 128.4(2 \mathrm{C}), 139.6(2 \mathrm{C})$, 145.8 (2C), 146.7 (4C), $164.5(2 \mathrm{C}=\mathrm{O})$; ESI-MS $462.7(\mathrm{M}-\mathrm{H})^{-}$.

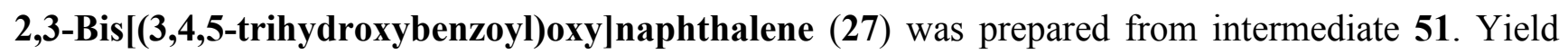
$60 \%$.

2,6-Bis[(3,4,5-trihydroxybenzoyl)oxy]naphthalene (28) was prepared from intermediate 52. Yield $54 \%$.

4,4'-Bis[(3,4,5-trihydroxybenzoyl)oxy]-1,1'-biphenyl (30) was prepared from intermediate 54. Yield 70\%; mp $268{ }^{\circ} \mathrm{C}(\mathrm{dec})$; IR (KBr) v 3396, 1701, 1608, $1192 ;{ }^{1} \mathrm{H}$ NMR (300 MHz, CD $\left.{ }_{3} \mathrm{OD}\right) \delta 7.24$ (s, 4H, gal), 7.24-7.28 (m, 4H, biphenyl), 7.67-7.71 (m, 4H, biphenyl); ${ }^{13} \mathrm{C}$ NMR (50 MHz, CD $\left.{ }_{3} \mathrm{OD}\right) \delta$ $110.8(4 \mathrm{CH}), 120.8(2 \mathrm{C}), 123.5,129.2(8 \mathrm{CH}), 139.4(2 \mathrm{C}), 140.6$ (2C), 146.9 (4C), $152.4(2 \mathrm{C}), 167.2$ $(2 \mathrm{C}=\mathrm{O})$; ESI-MS $488.8(\mathrm{M}-\mathrm{H})^{-}$.

General procedure for the synthesis of final compounds $13,15,16,19,22,24-26$, and 29 . To a solution of tert-butyldimethylsilyl derivative $39,41,42,45,46,48-50$, and 53 in a mixture of pyridine $(5.8 \mathrm{~mL} / \mathrm{mmol})$ and THF $(11.5 \mathrm{~mL} / \mathrm{mmol}), \mathrm{HF} \cdot$ py complex $(5.8 \mathrm{~mL} / \mathrm{mmol})$ was added, and the reaction 
was stirred at room temperature. After the complete disappearance of starting material (TLC) the reaction mixture was diluted with water $(50 \mathrm{~mL} / \mathrm{mmol})$ and the crude was extracted with ethyl acetate. The organic layers were then combined, washed with saturated aqueous $\mathrm{CuSO}_{4}$, dried over $\mathrm{MgSO}_{4}$, and concentrated under reduced pressure. The obtained off-white solid was recrystallized from $\mathrm{DCM} /$ methanol, to afford pure title compound.

Methyl 2,5-bis[(3,4,5-trihydroxybenzoyl)oxy]benzoate (13) was prepared from intermediate 39. Yield $70 \%$.

cis-1,4-Bis $[(3,4,5$-trihydroxybenzoyl)oxy]-1,2,3,4-tetrahydronaphthalene (15) was prepared from intermediate 41. Yield 88\%.

trans-1,4-Bis $[(3,4,5$-trihydroxybenzoyl)oxy]-1,2,3,4-tetrahydronaphthalene (16) was prepared from intermediate 42. Yield 62\%; mp $225{ }^{\circ} \mathrm{C}$ (dec); IR (neat) v 3351, 1683, 1612, 1214; ${ }^{1} \mathrm{H}$ NMR $(300$ MHz, acetone- $\left.d_{6}\right) \delta 2.09-2.15(\mathrm{~m}, 2 \mathrm{H}$, tetrahydronaph), 2.43-2.47 (m, 2H, tetrahydronaph), $6.23(\mathrm{~s}, 2 \mathrm{H}$, tetrahydronaph), $7.12(\mathrm{~s}, 4 \mathrm{H}$, gal), 7.37-7.47 (m, 4H, tetrahydronaph), 8.07 (br s, 2H, OH), 8.20 (br s, $4 \mathrm{H}, \mathrm{OH}) ;{ }^{13} \mathrm{C}$ NMR $\left(75 \mathrm{MHz}\right.$, acetone- $\left.d_{6}\right) \delta 25.8\left(2 \mathrm{CH}_{2}\right), 69.8(2 \mathrm{CH}), 109.9(4 \mathrm{CH}), 122.0(2 \mathrm{C}), 129.6$, $130.5(4 \mathrm{CH}), 136.6,139.9$ (4C), $146.1(4 \mathrm{C}), 166.2,167.0(2 \mathrm{C}=\mathrm{O})$; ESI-MS 467.0 (M - H $)^{-}$.

1,2-Bis[(3,4,5-trihydroxybenzoyl)oxy]naphthalene (19) was prepared from intermediate 45. Yield $80 \%$.

Methyl 1,4-bis[(3,4,5-trihydroxybenzoyl)oxy]-2-naphthoate (22) was prepared from intermediate 46. Yield $70 \%$.

1,6-Bis[(3,4,5-trihydroxybenzoyl)oxy]naphthalene (24) was prepared from intermediate 48. Yield $60 \%$.

1,7-Bis[(3,4,5-trihydroxybenzoyl)oxy]naphthalene (25) was prepared from intermediate 49. Yield $69 \%$.

1,8-Bis[(3,4,5-trihydroxybenzoyl)oxy]naphthalene (26) was prepared from intermediate 50. Yield $78 \%$. 
2,7-Bis[(3,4,5-trihydroxybenzoyl)oxy]naphthalene (29) was prepared from intermediate 53. Yield $55 \% ; \mathrm{mp} 273{ }^{\circ} \mathrm{C}(\mathrm{dec}) ; \mathrm{IR}(\mathrm{KBr}) \vee 3389,1687,1610,1146 ;{ }^{1} \mathrm{H} \mathrm{NMR}\left(300 \mathrm{MHz}, \mathrm{CD}_{3} \mathrm{OD}\right) \delta 7.26(\mathrm{~s}, 4 \mathrm{H}$, gal), 7.35 (dd, $J=8.9,2.1,2 \mathrm{H}$, naph), 7.70 (d, $J=2.1,2 \mathrm{H}$, naph), 7.99 (d, $J=8.9,2 \mathrm{H}$, naph); ${ }^{13} \mathrm{C}$ NMR (75 MHz, $\left.\mathrm{CD}_{3} \mathrm{OD}\right) \delta 109.6(4 \mathrm{CH}), 118.6(2 \mathrm{CH}), 119.5(2 \mathrm{C}), 121.5,129.3(4 \mathrm{CH}), 129.8,134.9(2 \mathrm{C})$, 139.6, $145.7(6 \mathrm{C}), 150.0(2 \mathrm{C}), 166.1(2 \mathrm{C}=\mathrm{O})$; ESI-MS $487.0(\mathrm{M}+\mathrm{Na})^{+}$.

Biochemistry. EGCG，3-(4,5-dimethyl-1,3-thiazol-2-yl)-2,5-diphenyl-2H-tetrazol-3-ium bromide (MTT), EDTA, dithiotreitol, acetyl-CoA, malonyl-CoA, and NADPH were purchased from Sigma (St. Louis, MO, USA), and 2 from Alexis Biochemicals (San Diego, CA, USA). Monoclonal anti- $\beta$-actin mouse antibody (C-4), monoclonal anti-FASN, polyclonal anti- $\beta$-actin and polyclonal Her-2 (Neu-C18) rabbit antibody were from Santa Cruz Biotechnology (Santa Cruz, CA, USA). Antibody against phospho-Her-2 (C-erb-2 Ab18) was mouse monoclonal from Thermo Fisher (Fremont, CA, USA). Rabbit polyclonal antibodies against PARP, AKT, phospho-AKT ${ }^{\text {Ser473 }}$, ERK-1 and -2, and mouse monoclonal antibodies against phospho-ERK-1 and -2 were from Cell Signaling Technology (Denvers, MA, USA). Peroxidase-conjugated secondary antibodies were from Calbiochem (San Diego, CA, USA). CPT-1 activity assay was done using palmitoyl-CoA lithium salt from Sigma (St. Louis, MO, USA), fatty acid-free bovine serum albumin from Roche (Manheim, Germany), L-Carnitine hydrochloride from Sigma (St. Louis, MO, USA), and L-[methyl- $\left.{ }^{3} \mathrm{H}\right]$ carnitine hydrochloride ( $82 \mathrm{Ci} / \mathrm{mmol}$ ) from Amersham Biosciences.

Cell lines and cell culture. Cells were routinely incubated at $37{ }^{\circ} \mathrm{C}$ with $5 \% \mathrm{CO}_{2}$. MCF-7 and MDAMB-231 breast cancer cells were obtained from the American Type Culture Collection (ATCC, Rockville, MD, USA), and were routinely grown in Dulbecco's modified Eagle's medium (Gibco, Berlin, Germany) containing 10\% heat-inactivated fetal bovine serum (FBS, HyClone Laboratories, UT, USA), $1 \%$ L-glutamine, $1 \%$ sodium pyruvate, $50 \mathrm{U} / \mathrm{mL}$ penicillin, and $50 \mu \mathrm{g} / \mathrm{mL}$ streptomycin (Gibco). SK-Br3 breast cancer cells were obtained from Eucellbank (Barcelona, Spain), and were passaged in 
McCoy's 5A medium containing 10\% FBS, 1\% L-glutamine, 1\% sodium pyruvate, $50 \mathrm{U} / \mathrm{mL}$ penicillin, and $50 \mu \mathrm{g} / \mathrm{mL}$ streptomycin.

Cytotoxicity assay. Drug sensitivity was determined using a standard colorimetric MTT assay. Briefly, cells were plated out at a density of 5 or $7 \times 10^{3}$ cells/100 $\mu \mathrm{L} /$ well in 96 -well microtitre plates, and allowed an overnight period for attachment. Then the medium was removed and cells were incubated for $48 \mathrm{~h}$ with fresh medium containing different concentrations of EGCG or the corresponding compound 5-30. Following treatment, drug-free medium $(100 \mu \mathrm{L} /$ well $)$ and $10 \mu \mathrm{L}$ of a $5 \mathrm{mg} / \mathrm{mL}$ MTT solution were added and cells were incubated for $3 \mathrm{~h}$ at $37^{\circ} \mathrm{C}$. After careful removal of the supernatants, the MTT-formazan crystals formed by metabolically viable cells were dissolved in DMSO (100 $\mu \mathrm{L} /$ well) and absorbance was measured at $570 \mathrm{~nm}$ in a multi-well plate reader (Model Anthos Labtec 20101.7 ) or at $540 \mathrm{~nm}$ on a FlexStation 3 instrument.

FASN activity assay. After 6, 12 or $24 \mathrm{~h}$ of exposure to compound under study, cells were harvested by treatment with trypsin-EDTA solution, pelleted by centrifugation, washed twice, and resuspended in cold phosphate buffered solution (PBS). Cells were sonicated during $30 \mathrm{~min}$ at $4{ }^{\circ} \mathrm{C}$ (PSelecta Ultrasons) and centrifuged for $15 \mathrm{~min}$ at $4{ }^{\circ} \mathrm{C}$ to obtain particle-free supernatants. FASN activity, expressed in nmol NADPH oxidized $\mathrm{min}^{-1}$ protein $\mathrm{mg}^{-1}$, was assessed in particle-free supernatant samples of equal protein content (measured by the Lowry-based BioRad assay) by spectrophotometrically monitoring oxidation of NADPH at $340 \mathrm{~nm}$ as described. ${ }^{17}$

RNA interference-mediated silencing of the FASN gene. FASN siRNA (h), a pool of 3 targetspecific 19-25 nt siRNAs, commercially available from Santa Cruz Biotechnology, was used following the manufacturer's instructions to knock down FASN gene expression in SK-Br3 cells. To determine cytotoxicity in these cells, the MTT protocol indicated above was followed except for the fact that the percentage of cell viability was measured after $24 \mathrm{~h}$ incubation in the presence of compound $\mathbf{3 0}$.

\section{Immunoblot analysis of p185 ${ }^{\mathrm{HER} 2 / \mathrm{neu}}$, phospho-p185 ${ }^{\mathrm{HER} 2 / \mathrm{neu}}, \mathrm{ERK1} / 2$, phospho-ERK1/2, AKT,} phospho-AKT ${ }^{\text {Ser473 }}$ and PARP. Following treatment of SK-Br3 cells with EGCG or FASN inhibitor 30 at the corresponding concentration and for the indicated time, cells were harvested using trypsin-EDTA, 
washed twice with PBS, and stored at $-80{ }^{\circ} \mathrm{C}$. Cells were lysed in lysis buffer (1 mM EDTA, $150 \mathrm{mM}$ $\mathrm{NaCl}, 100 \mu \mathrm{g} / \mathrm{mL}$ phenylmethylsulfonyl fluoride $50 \mathrm{mM}$ Tris- $\mathrm{HCl}, \mathrm{pH} 7.5$ ) and kept at $4{ }^{\circ} \mathrm{C}$ while they were routinely mixed every $2 \mathrm{~min}$ on the vortex during $30 \mathrm{~min}$. A sample was taken for measurement of protein content by the Lowry-based BioRad assay. Equal amounts of protein were heated in sodium dodecylsulphate (SDS) sample buffer (Laemmli) for $5 \mathrm{~min}$ at $95{ }^{\circ} \mathrm{C}$, separated on a 3-8\% SDSpolyacrylamide gel $\left(\mathrm{p} 185^{\mathrm{HER} 2 / \mathrm{neu}}\right.$, phospho-p $\left.185^{\mathrm{HER} 2 / \mathrm{neu}}\right)$ or $4-12 \%$ SDS-polyacrylamide gel (AKT, phospho-AKT, ERK1/2, phospho-ERK1/2, and PARP), and transferred onto nitrocellulose membranes. Membranes were incubated for $1 \mathrm{~h}$ at room temperature in blocking buffer $(2.5 \%$ powdered-skim milk in tris-buffered solution with $0.05 \%$ Tween-20; TBS-T [10 mM Tris-HCl pH 8.0, $150 \mathrm{mM} \mathrm{NaCl}$, and $0.05 \%$ Tween-20]) to prevent non-specific antibody binding, and incubated with the corresponding primary antibody diluted in blocking buffer overnight at $4{ }^{\circ} \mathrm{C}$. After $3 \times 5$ min washes in TBS-T, blots were incubated for $1 \mathrm{~h}$ with corresponding peroxidase conjugated secondary antibody and developed employing a commercial kit (West Pico chemiluminescent substrate). Blots were re-probed with an antibody against $\beta$-actin as control of protein loading and transfer.

Measurement of CPT-1 activity. CPT-1 activity was assayed by the forward exchange method using $\mathrm{L}-\left[{ }^{3} \mathrm{H}\right]$ carnitine as we previously described. ${ }^{10}$ Briefly, reactions (total volume of $0.5 \mathrm{~mL}$ ) consisted in the standard enzyme assay mixture with $200 \mu \mathrm{M}$ of the corresponding FASN inhibitor, $2 \mathrm{mM}$ L$\left[{ }^{3} \mathrm{H}\right]$ carnitine ( 5000 dpm/nmol), $80 \mu \mathrm{M}$ palmitoyl-CoA, $20 \mathrm{mM}$ HEPES (pH 7.0), 1\% fatty acid-free albumin, and 40-75 mM KCl. Reactions were initiated by addition of isolated intact yeast mitochondria. The reaction was linear up to $4 \mathrm{~min}$ and all incubations were done at $30{ }^{\circ} \mathrm{C}$ for $3 \mathrm{~min}$. Reactions were stopped by addition of $6 \%$ perchloric acid and were then centrifuged at $2500 \mathrm{rpm}$ for $5 \mathrm{~min}$. The resulting pellet was suspended in water and the product $\left[{ }^{3} \mathrm{H}\right]$ palmitoylcarnitine was extracted with butanol at low $\mathrm{pH}$. After centrifugation at $2300 \mathrm{rpm}$ for $3 \mathrm{~min}$, an aliquot of the butanol phase was transferred to a vial and counted by liquid scintillation. To perform the assay, mitochondria from GS115 Pichia pastoris transformants that express Rat CTPIA were isolated by disrupting the yeast cells with glass beads as previously described. ${ }^{10}$ 
In vivo experiments. Male mice C57BL/6J (12 weeks, 23-25 g) were purchased from Harlan Laboratories (France), fed ad libitum with a standard rodent chow and housed in a light/dark $12 \mathrm{~h} / 12 \mathrm{~h}$ cycle at $22{ }^{\circ} \mathrm{C}$ for one week. Animals were randomized into four groups (treated with vehicle or compounds 2, 4 or 30) of 4 animals each. All experiments were done in accordance with guidelines on animal care and use established by University of Barcelona School of Farmacia Institutional Ethic and Scientific Committee (Barcelona, Spain). Treatments were done as previously described. ${ }^{11,30}$ Briefly, mice were fasted for $12 \mathrm{~h}$ during the dark cycle before treatment. Each group received a single i.p. injection (0.5 mL) of FASN inhibitor at the corresponding dose or vehicle alone (DMSO), dissolved in RPMI 1640 medium. After i.p. injections, mice were given free access to rodent chow for $24 \mathrm{~h}$. At this time, the experiment finished and body weight was registered.

Statistical analysis for in vivo studies. Results were analyzed by Student's $t$ test or by one-way ANOVA using a Tukey test as a post-test. $P<0.05$ was considered statistically significant. All data are means \pm SD. All observations were confirmed by at least three independent experiments.

Supporting Information Available. Spectral characterization data of protected esters 31-38, 41-52, and 54 and final compounds 5-15, 18-22, 24-28, as well as HPLC-MS analysis of purity for all final compounds 5-30. This material is available free of charge via the Internet at http://pubs.acs.org

Acknowledgment. This work was supported by grants from the Spanish Ministerio de Economía y Competitividad (MINECO, SAF2010-22198-C02-01, M.L.L.-R.; SAF2010-15217, D.H.; CIT0900002008-10, T.P., and predoctoral fellowship to C.T.), the Spanish Instituto de Salud Carlos III (FIS PI082031, R.C. and T.P.), the Catalan government (2009SGR163, D.H.), Comunidad de Madrid (S2010/BMD-2353), and the Spanish Society of Medical Oncology (SEOM08, T.P.). S.O.-G. is a Ramon y Cajal Scholar funded by MICINN and the European Social Fund. 


\section{References}

(1) Abramson, H.N. The lipogenesis pathway as a cancer target. J. Med. Chem. 2011, 54, 5615-5638.

(2) Kuhajda, F.P.; Jenner, K.; Wood, F.D.; Hennigar, R.A.; Jacobs, L.B.; Dick, J.D.; Pasternack, G.R. Fatty acid synthesis: a potential selective target for antineoplastic therapy. Proc. Natl. Acad. Sci. USA 1994, 91, 6379-6383.

(3) Liu, H.; Liu, J.-Y.; Wu, X.; Zhang, J.-T. Biochemistry, molecular biology, and pharmacology of fatty acid synthase, an emerging therapeutic target and diagnosis/prognosis marker. Int. J. Biochem. Mol. Biol. 2010, 18, 69-89.

(4) Migita, T.; Ruiz, S.; Fornari, A.; Fiorentino, M.; Priolo, C.; Zadra, G.; Inazuka, F.; Grisanzio, C.; Palescandolo, E.; Shin, E.; Fiore, C.; Xie, W.; Kung, A.L.; Febbo, P.G.; Subramanian, A.; Mucci, L.; Ma, J.; Signoretti, S.; Stampfer, M.; Hahn, W.C.; Finn, S.; Loda, M. Fatty acid synthase: a metabolic enzyme and candidate oncogene in prostate cancer. J. Natl. Cancer Inst. 2009, 101, 519-532.

(5) Omura, S. The antibiotic cerulenin, a novel tool for biochemistry as an inhibitor of fatty acid synthesis. Bacteriol. Rev. 1976, 40, 681-697.

(6) Lupu, R.; Menendez, J.A. Pharmacological inhibitors of fatty acid synthase (FASN)-catalyzed endogenous fatty acid biogenesis: a new family of anti-cancer agents? Curr. Pharm. Biotechnol. 2006, 7, 483-493.

(7) Kuhajda, F.P.; Pizer, E.S.; Li, J.N.; Mani, N.S.; Frehywot, G.L.; Townsend, C.A. Synthesis and antitumor activity of an inhibitor of fatty acid synthase. Proc. Natl. Acad. Sci. USA 2000, 97, 3450-3454.

(8) Rendina, A.R.; Cheng, D. Characterization of the inactivation of rat fatty acid synthase by C75: inhibition of partial reactions and protection by substrates. Biochem. J. 2005, 388, 895-903.

(9) Yang, N.; Kays, J.S.; Skillman, T.R.; Burris, L.; Seng, T.W.; Hammond, C. C75 [4-methylene-2octyl-5-oxo-tetrahydro-furan-3-carboxylic acid] activates carnitine palmitoyltransferase-1 in isolated 
mitochondria and intact cells without displacement of bound malonyl CoA. J. Pharmacol. Exp. Ther. $\mathbf{2 0 0 5}, 312,127-133$.

(10) Nicot, C.; Napal, L.; Relat, J.; Gonzalez, S.; Llebaria, A.; Woldegiorgis, G.; Marrero, P.F.; Haro, D. C75 activates malonyl-CoA sensitive and insensitive components of the CPT system. Biochem. Biophys. Res. Commun. 2004, 325, 660-664.

(11) Thupari, J.N.; Landree, L.E.; Ronnett, G.V.; Kuhajda, F.P. C75 increases peripheral energy utilization and fatty acid oxidation in diet-induced obesity. Proc. Natl. Acad. Sci. USA 2002, 99, 94989502.

(12) Kridel, S.J.; Axelrod, F.; Rozenkrantz, N.; Smith, J.W. Orlistat is a novel inhibitor of fatty acid synthase with antitumor activity. Cancer Res. 2004, 64, 2070-2075.

(13) Yang, C.S.; Wang, X.; Lu, G.; Picinich, S. C. Cancer prevention by tea: animal studies, molecular mechanisms and human relevance. Nat. Rev. Drug Discov. 2009, 9, 429-439.

(14) Wang, X.; Tian, W. Green tea epigallocatechin gallate: a natural inhibitor of fatty-acid synthase. Biochem. Biophys. Res. Commun. 2001, 288, 1200-1206.

(15) Brusselmans, K.; De Schrijver, E.; Heyns, W.; Verhoeven, G.; Swinnen, J.V. Epigallocatechin-3gallate is a potent natural inhibitor of fatty acid synthase in intact cells and selectively induces apoptosis in prostate cancer cells. Int. J. Cancer 2003, 106, 856-862.

(16) Vergote, D.; Cren-Olive, C.; Chopin, V.; Toillon, R.A.; Rolando, C.; Hondermarck, H.; Le Bourhis, X. (-)-Epigallocatechin (EGC) of green tea induces apoptosis of human breast cancer cells but not of their normal counterparts. Breast Cancer Res. Treat. 2002, 76, 195-201.

(17) Puig, T.; Vazquez-Martin, A.; Relat, J.; Petriz, J.; Menendez, J.A.; Porta, R.; Casals, G.; Marrero, P.F.; Haro, D.; Brunet, J.; Colomer, R. Fatty acid metabolism in breast cancer cells: differential 
inhibitory effects of epigallocatechin gallate (EGCG) and C75. Breast Cancer Res. Treat. 2008, 109, 471-479.

(18) Nakagawa, K.; Miyazawa, T. Chemiluminescence-high-performance liquid chromatographic determination of tea catechin, (-)-epigallocatechin 3-gallate, at picomole levels in rat and human plasma. Anal. Biochem. 1997, 248, 41.

(19) Colomer, R; Puig, T.; Brunet, J.; López-Rodríguez, M.L.; Benhamú, B.; Ortega-Gutiérrez, S.; Turrado, C. PCT/EP2008/058099, WO 2009/000864 A1.

(20) Puig, T.; Turrado, C.; Benhamú, B.; Aguilar, H.; Relat, J.; Ortega-Gutiérrez, S.; Casals, G.; Marrero, P.F.; Urruticoechea, A.; Haro, D.; López-Rodríguez, M.L.; Colomer, R. Novel inhibitors of fatty acid synthase with anticancer activity. Clin. Cancer Res. 2009, 15, 7608-7615.

(21) Ren, Y.; Himmeldirk, K.; Chen, X. Synthesis and structure-activity relationship study of antidiabetic penta-O-galloyl-D-glucopyranose and its analogs. J. Med. Chem. 2006, 49, 2829-2837.

(22) Nakazono, M.; Ma, L.; Zaitsu, K. Synthesis of poly (3,4,5-trihydroxybenzoate ester)dendrimers and their chemiluminescence. Tetrahedron Lett. 2002, 43, 8185-8189.

(23) Feldman, K.S.; Sambandam, A.; Bowers, K.E.; Appel, H.M. Probing the role of polyphenol oxidation in mediating insect-pathogen interactions. Galloyl-derived electrophilic traps for the Lymantria dispar nuclear polyhedrosis virus matrix protein polyhedrin. J. Org. Chem. 1999, 64, 57945803

(24) Kündig, E.P.; Enriquez-Garcia, A. Diastereoselective and enantioselective reduction of tetralin1,4-dione. Beilstein J. Org. Chem. 2008, 4, doi:10.3762/bjoc.4.37.

(25) Fieser, L.F.; Fieser, M. The synthesis from $\beta$-naphthohydroquinone of a tautomer of 4-benzyl-1,2naphthoquinone. J. Am. Chem. Soc. 1939, 61, 596-608. 
(26) Adams, S.P.; Whitlock H.W. Jr. Synthesis, conformation, and complexation behavior of 2,9,18,25-tetraoxa[8.8](1,4)naphthalenophane. J. Org. Chem. 1971, 46, 3474-3478.

(27) Ono, K.; Yamaguchi, H.; Taga, K.; Saito, K.; Nishida, J.; Yamashita, Y. Synthesis and properties of $\mathrm{BF}_{2}$ complexes to dihydroxydiones of tetracene and perylene: novel electron acceptors showing $\mathrm{n}$ type semiconducting behavior. Org. Lett. 2009, 11, 149-152.

(28) Menendez, J.A.; Vellon, L.; Mehmi, I.; Oza, B.P.; Ropero, S.; Colomer, R.; Lupu, R. Inhibition of fatty acid synthase (FAS) suppresses HER2/neu (erbB-2) oncogene overexpression in cancer cells. Proc. Natl. Acad. Sci. USA 2004, 101, 10715-10720.

(29) Gooding, O.W.; Vo, L.; Bhattacharyya, S.; Labadie, J.W. Use of statistical design of experiments in the optimization of amide synthesis utilizing polystyrene-supported $N$-hydroxybenzotriazole resin. $J$. Comb. Chem. 2002, 4, 576-583.

(30) Loftus, T.M.; Jaworsky, D.E.; Frehywot, G.L.; Townsend, C.A.; Ronnett, G.V.; Lane, M.D.; Kuhajda, F.P. Reduced food intake and body weight in mice treated with fatty acid synthase inhibitors. Science 2000, 288, 2379-2381. 
Table 1. Cytotoxicity in SK-Br3 breast cancer tumor cells and inhibition of FASN activity of compounds 5-30<smiles>CCCCCOC(=O)c1cc(O)c(O)c(O)c1</smiles>

5-30

\begin{tabular}{|c|c|c|c|c|c|c|c|}
\hline Comp. & A Subunit & $\begin{array}{c}\mathrm{IC}_{50} \\
(\mu \mathrm{M})^{a}\end{array}$ & $\begin{array}{l}\text { FASN } \\
\text { inhib. } \\
(\%)^{a, b}\end{array}$ & Comp. & A Subunit & $\begin{array}{c}\text { IC }_{50} \\
(\mu \mathrm{M})^{a}\end{array}$ & $\begin{array}{l}\text { FASN } \\
\text { inhib. } \\
(\%)^{a, b}\end{array}$ \\
\hline 5 & & $>150$ & N.D. & 18 & & $41 \pm 3$ & N.I. \\
\hline $6^{c}$ & & $>150$ & N.D. & 19 & & $74 \pm 2$ & N.D. \\
\hline $7^{c}$ & & $>150$ & N.D. & $\mathbf{2 0}^{c}$ & & $21 \pm 7$ & $90 \%$ \\
\hline $8^{c}$ & & $125 \pm 5$ & N.D. & $\mathbf{2 1}{ }^{c}$ & & $29.0 \pm 0.3$ & $69 \%$ \\
\hline $9^{c}$ & & $42 \pm 7$ & N.I. & 22 & & $28 \pm 6$ & N.I. \\
\hline $10^{c}$ & & $25 \pm 4$ & N.I. & 23 & & $26 \pm 3$ & $30 \%$ \\
\hline
\end{tabular}




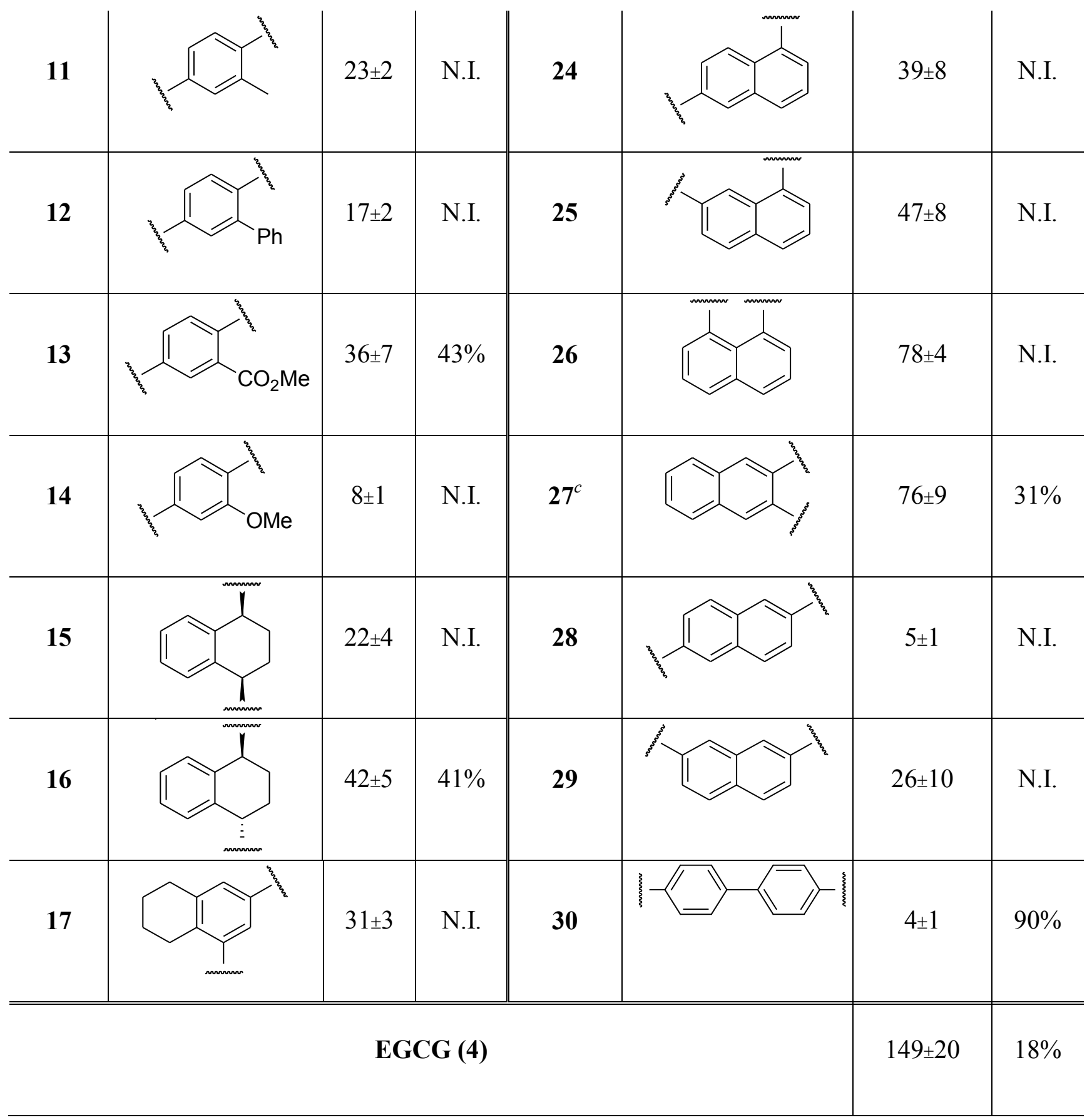

${ }^{a}$ The values are the mean ${ }_{ \pm}$SEM from two independent experiments performed in triplicate. ${ }^{b}$ FASN inhibition values are determined at a concentration equal to the $\mathrm{IC}_{50}$ value of the cytotoxicity of the compound in SK-Br3 cells. ${ }^{c}$ Data are from reference 20. N.D., not determined. N.I., no significant inhibition of FASN activity at the tested concentration. 
Table 2. Cytotoxicity of compound $\mathbf{3 0}$ in different human cancer cell lines

\begin{tabular}{|c|c|c|}
\hline $\begin{array}{l}\text { Tissue } \\
\text { origin }\end{array}$ & Cell line & $\mathrm{IC}_{50}(\mu \mathrm{M})^{a}$ \\
\hline Colon & HCT116 & $4 \pm 2$ \\
\hline Pancreas & PANC-1 & $2.1 \pm 0.5$ \\
\hline Skin & A431 & $1.4 \pm 0.1$ \\
\hline \multirow{3}{*}{ Liver } & Bel-7402 & $40 \pm 3$ \\
\hline & SK-Hep1 & $56 \pm 5$ \\
\hline & HepG2 & $70 \pm 21$ \\
\hline Ovary & SKOV3 & $5 \pm 2$ \\
\hline \multirow{6}{*}{ Breast } & SK-Br3 & $4 \pm 1$ \\
\hline & MCF-7 & $3.8 \pm 0.8$ \\
\hline & ZR-75-1 & $1.9 \pm 0.3$ \\
\hline & MDA-MB-231 & $5 \pm 3$ \\
\hline & BT-20 & $17 \pm 2$ \\
\hline & AU565 & $24 \pm 5$ \\
\hline \multirow{3}{*}{ Lung } & HCC 827 & $14 \pm 8$ \\
\hline & H460 & $9 \pm 1$ \\
\hline & A549 & $17 \pm 10$ \\
\hline
\end{tabular}

${ }^{a}$ The values are the mean + SEM from at least two independent experiments performed in duplicate or triplicate. 
Scheme 1. Synthesis of final compounds $5-30{ }^{a}$

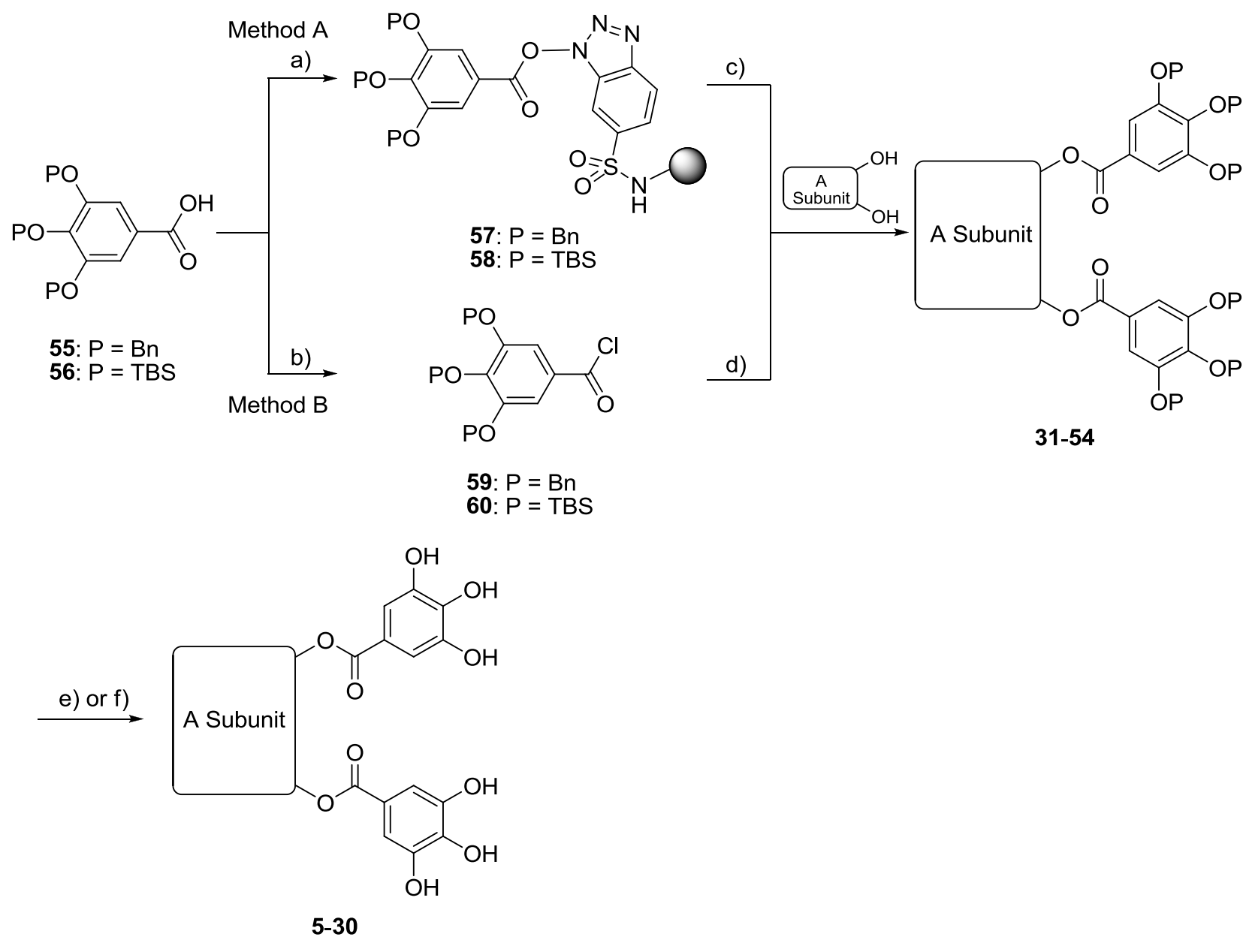

${ }^{a}$ Reagents and conditions: a) PS-HOBt, DIC, DMAP, DCM, rt, quantitative; b) $(\mathrm{COCl})_{2}$, DMF, toluene, $55{ }^{\circ} \mathrm{C}$, quantitative; c) DIEA, THF, rt, 20-77\%; d) TEA, THF, rt, 24-53\%; e) $\mathrm{H}_{2}, \mathrm{Pd}(\mathrm{OH})_{2} / \mathrm{C}, \mathrm{EtOH}$, DCM (P = Bn), rt, 54-95\%; f) HF·py, pyridine, THF (P = TBS), rt, 55-88\%. 
<smiles>C/C=C/C/C=C/CCC(=O)C1OC1C(N)=O</smiles>

Cerulenin (1)<smiles>C=C1C(=O)O[C@@H](C=CC)C1C(=O)O</smiles>

C75 (2)

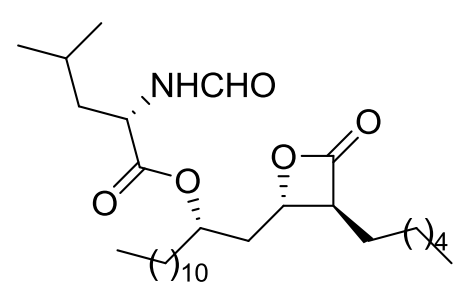

Orlistat (3)<smiles>O=C(O[C@H]1Cc2c(O)cc(O)cc2O[C@H]1c1cc(O)c(O)c(O)c1)c1cc(O)c(O)c(O)c1</smiles>

EGCG (4)<smiles>CCCCCOC(=O)c1cc(O)c(O)c(O)c1</smiles>

5-30

Chart 1. Reported FASN inhibitors cerulenin (1), C75 (2), orlistat (3), and (-)-epigallocatechin 3-gallate (EGCG, 4), and new compounds 5-30. 


\section{LEGENDS FOR FIGURES}

Figure 1. (A) Effect of siRNA-induced silencing of FASN gene expression on cytotoxicity induced by compound 30. Cytotoxicity of compound $\mathbf{3 0}$ at different concentrations (white bars) is eliminated by siRNA-induced reduction of FASN expression levels (black bars). (B) SK-Br3 breast cancer cells were transfected with siRNA-targeting FASN for $72 \mathrm{~h}$. Equal amounts of total protein from SK-Br3 cells transfected with siRNA-targeting FASN or with the control were subjected to immunoblotting analyses with antibodies against FASN or $\beta$-actin. Results shown in panel $\mathrm{A}$ are the average $\pm \mathrm{SEM}$ of three different experiments performed in duplicate. Gels shown in panel B are representative of those obtained in two independent experiments. ${ }^{*} \mathrm{p}<0.01$ (Student's t-test) $v s$ the same concentration of compound 30 in control-transfected cells.

Figure 2. FASN expression levels in different breast (A) and liver (B) cancer cell lines. Equal amounts of total protein were subjected to immunoblotting analysis with a monoclonal antibody against FASN. Immunoreactive bands in the figure are from one representative experiment. Equivalent results were found in two to four independent experiments. Blots were re-probed with an antibody for $\beta$-actin to control for protein loading and transfer (not shown for the sake of clarity).

Figure 3. Compound 30 (A) induces apoptosis as assessed by PARP cleavage (note intact PARP at 116 $\mathrm{kDa}$ and its cleavage product at $89 \mathrm{kDa}$ ); and (B) blocks the activation of HER2, AKT and ERK1/2 signaling pathways. SK-Br3 cells were treated with $\mathbf{3 0}$ for 6,12 or $24 \mathrm{~h}$, and equal amounts of lysates were immunoblotted with the corresponding antibody. Blots were re-probed for $\beta$-actin as loading control. In all cases, shown gels are representative of those obtained from at least two independent experiments. 
Figure 4. Compound 30 (A) does not modulate CPT-1 activity in vitro and (B) does not induce weight loss in vivo in a similar manner to EGCG (4) and in sharp contrast to 2, both included in the Figure for comparative purposes. CPT-1 activity was determined in intact yeast mitochondria as a source of enzyme in the absence or presence of the corresponding compound. For determination of the effect of the compounds in body weight, mice were fasted for $12 \mathrm{~h}$, treated with a single i.p. $(30,50 \mathrm{or} 75 \mathrm{mg} / \mathrm{kg}$ ) dose of the compound under study or vehicle as indicated, refed for $24 \mathrm{~h}$, and body weight was registered. Results shown are the average \pm SEM of a least three different experiments with independent mitochondrial preparations (panel $\mathrm{A}$ ) or the average $\pm \mathrm{SEM}, \mathrm{n}=4$ (panel B). 
Figure 1

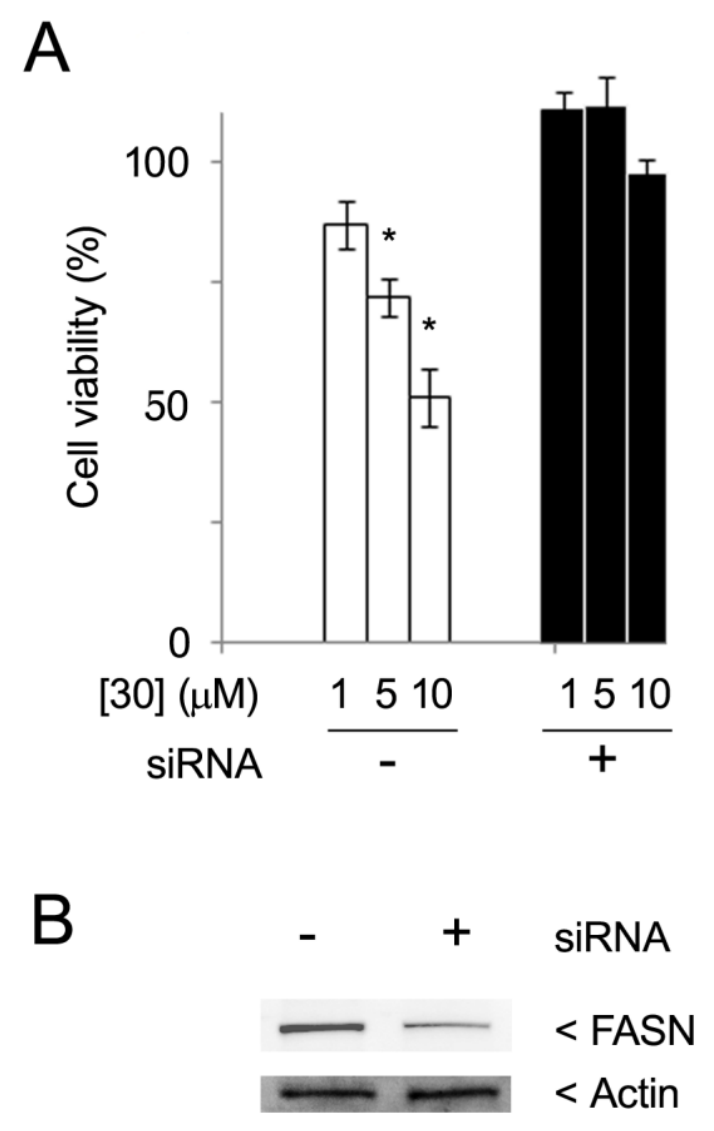


Figure 2

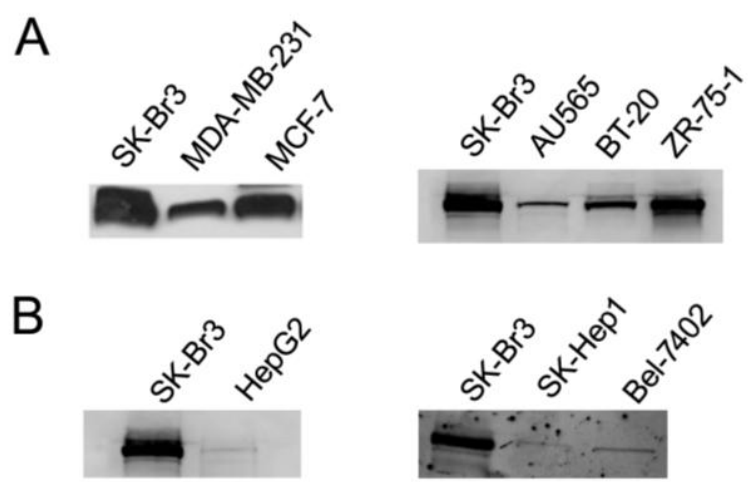


Figure 3

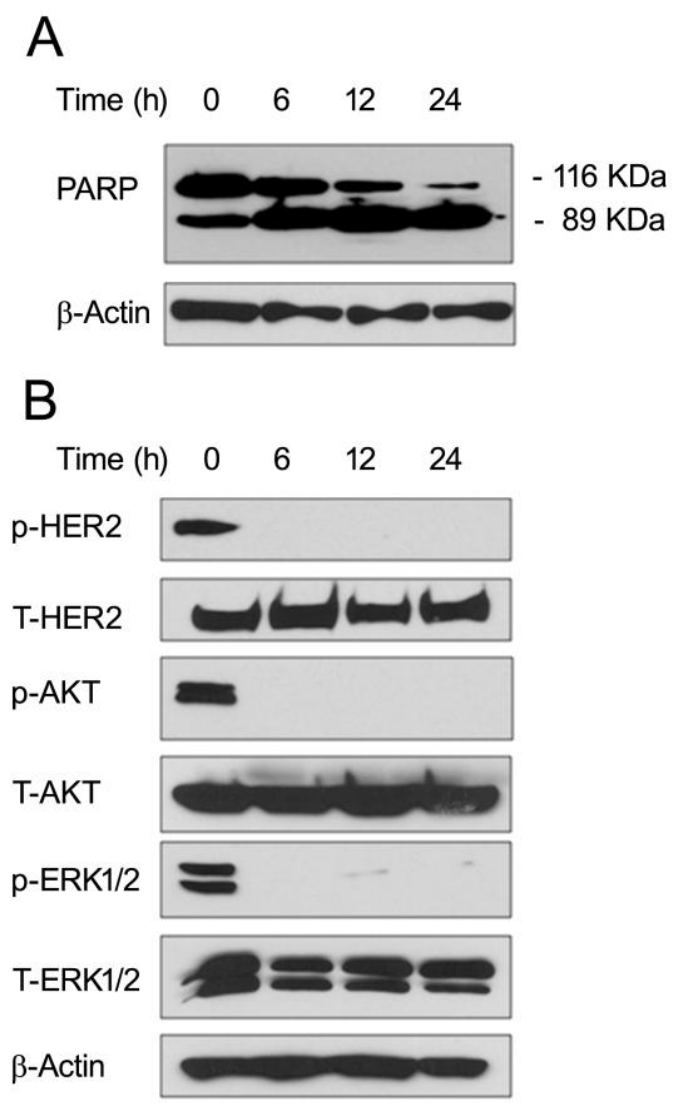


Figure 4

A

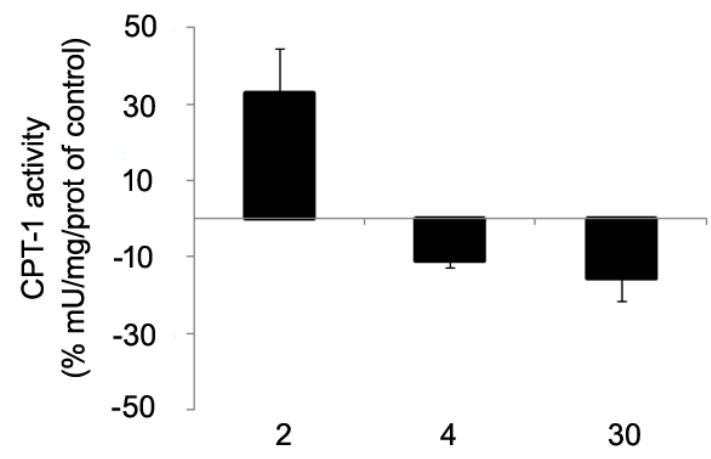

B

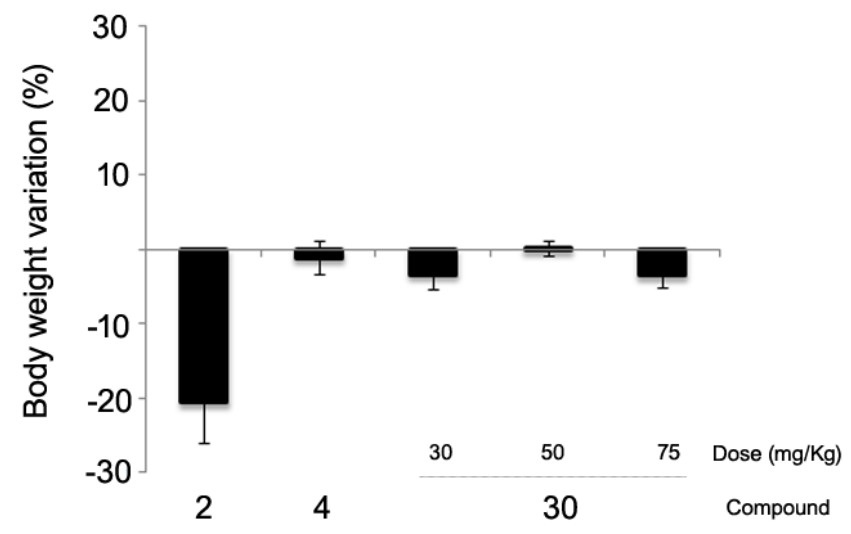




\section{Table of contents (TOC) graphic}

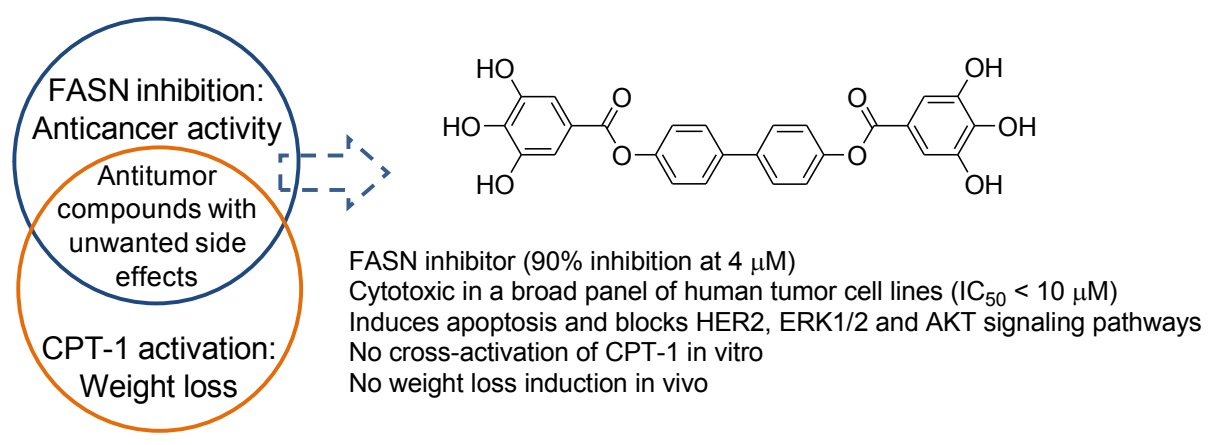

